\title{
Tüz elleni védekezés a polgári magyar államban 1867-1945
}

DOI : 10.31627/RTF.XXIV.2014.35-36-37-38N.85-110P

A polgári magyar államot az 1848-1849-es magyar forradalom és szabadságharc hozta létre. Ezen időszakot azonban fegyveres konfliktus uralta, ezért nem a tüzoltó szervetek szabályozása bizonyult a legsürgetőbb feladatnak.

A cári haderő hathatós támogatásával a HABSBURG-hatalomnak ugyan sikerült levernie az 18481849-es magyar forradalom és szabadságharcot, azonban a rendiségen nyugvó társadalmi berendezkedés visszaállítása már nem volt célszerü. A neoabszolutizmus állama lényegében polgári állam volt az uralkodó (államfó) teljhatalmával, a demokrácia mellőzésével. Egyben pedig, a neoabszolutizmus mellőzte a magyar nemzeti jelleget. Megszüntette a magyar államot. A Magyar Királyság területét 5 tartományra osztotta, amelyek az uralkodó korlátokat nélkülöző felügyelete alá tartoztak. A herceg SCHWARZENBERG Félix miniszterelnöktől származó úgynevezett „Verwirkungstheoire” (jogeljátszás elmélet) álnok elmélete szolgáltatta a neoabszolutizmus elvi alapját. E szerint ugyanis az uralkodója ellen fellázadt nemzet minden jogát elveszti. ${ }^{1}$ Ezen hazug koncepció mögött nyilvánvalóan a nagynémet egység létrehozására törekvés állt. Nevezetesen a HABSBURG-birodalmat szerették volna elnémetesíteni és a német tartományokkal egy birodalomban egyesíteni HABSBURG vezetéssel. A középeurópai birodalom gondolata azonban elbukott. Helyette létrejött a kisnémet egység porosz vezetéssel. A HABSBURG-birodalom vereséget szenvedett Solferino-nál (1859. VI. 24.), Königgrätz-nél (1866. VII. 3.). A passzív rezisztencia megdrágította a neoabszolutista rendszer müködését, amire pedig fóként a fegyveres eröszakszervezetekre - nagy szükség volt a hatalom nemzetellenes politikája miatt. A gyengülő HABSBURG-birodalom számára felértékelődött a magyarokkal való megegyezés lehetősége. ${ }^{2} \mathrm{Az}$ uralkodó - akinek az uralkodása a magyar törvények szerint illegitim volt — által oktrojált alkotmány ugyan tartalmazta, hogy a belső rend biztosítása birodalmi ügy, ebbe azonban a tüzoltást nem tekintették beletartozónak. A HABSBURG hatalom birodalmi tüzoltószervezetet nem hozott létre, ellentétben a közrend biztosítása érdekében felállított birodalmi csendőrséggel. Kétségtelen azonban, hogy - báró Franz Johann KEMPEN von Fichtenstamm altábornagy által irányított - Császári Királyi Csendőrség nem csupán a közrendet biztosította, hanem a császári hatalom hathatós elnyomó szervezetének is bizonyult. ${ }^{3}$ Mivel a tüzoltó szervezetektől ilyen tevékenység nyilvánvalóan nem lett volna elvárható, ezért a központi hatalom nem tartotta fontosnak a tüzvédelem birodalmi szervezetként történő megvalósítását.

A neoabszolutizmus viszonyai között nem meglepő, hogy a császári hatóságok ódzkodtak mindenfajta társadalmi szervezet létrehozásának engedélyezésétől, mivel okkal tartottak attól, hogy azok a nemzeti ellenállás álcázott szervezeteivé válhattak volna. A neoabszolutizmus enyhébb és keményebb időszakai egyaránt magyarellenesek voltak, csupán a módszerek változtak. Ebből fakadóan tüzoltó szervezetek létrehozását ott engedélyezték, ahol a legcsekélyebb lehetőségét látták annak, hogy a szervezetek a nemzeti érzület kifejeződésének a kereteivé váljanak. A hatalom gyakorlói úgy gondolták, hogy erre a legkisebb esély a zömében német ajkú polgárok által lakott városokban kínálkozott. Így jöhetett létre például hosszadalmas engedélyezési procedúra nyomán Sopronban tüzoltóság a kiegyezés elött. ${ }^{4}$

A kiegyezéssel azonban lényegesen megváltoztak a körülmények. Helyreállt az 1849-ben külső haderő segítségével felszámolt polgári magyar állam. A kiegyezés utáni polgári magyar állam időszakában sem tekintették azonban szükségesnek a kormányok állami tüzoltóság létrehozását. A témakört azonban számos jogszabályban szabályozták. Elősegítették továbbá a tüzoltás társadalmi szervezetrendszerének a kiépülését. E szövetség számára szakigazgatási jogköröket is biztosítottak. A tüzoltókat beemelték a közhatósági jogú személyek közé. E folyamat nem egyik napról a másikra ment végbe, hanem több évtizedes fejlődés során. Végül pedig — a magyar állam átalakításának a részeként létrejött az állami túzoltóság, de már nem a polgári magyar állam időszakában. ${ }^{5}$

A neoabszolutizmustól a Magyar Királyság olyan vegyes tüzoltó szervezetet örökölt, amelyben már jelen voltak a városi és a gyári tüzoltóságok is, de még megtalálhatók voltak a céhes tüzoltóságok is. ${ }^{6} \mathrm{Az}$ 1872. évi ipartörvény nyomán azonban a céhes tüzoltóságok elenyésztek. ${ }^{7}$ Felgyorsult a települési és a gyári tüzoltó szervezetek létrehozása. ${ }^{8}$

A tüzrendészetet a Magyar Királyi Belügyminisztérium számos rendelettel szabályozta. Már a tüzvédelemmel foglalkozó 1869-ben kiadott belügyminiszteri körlevél 7. pontja is elöírta, hogy „ . . . minden helységben a helyi .viszonyoknak megfelelö tüzőrség szerveztessék, s ott hol ez kivihető, tüzoltóegyletek létesítessenek." "9.sz. melléklet)

1870-ben létrejött a Magyar Országos Tủzoltó Szövetség. 1878-ban pedig belügyi tárca a Magyar Országos Tüzoltó Szövetséget szakközegként ismerte el. ${ }^{10}$ (II.sz. melléklet) Ezzel a magyar állam el- 
ismerte, hogy a tüzoltási szakértelem Magyarországon a Magyar Országos Tüzoltó Szövetségben található. A szövetség pedig valóban biztosítani igyekezett a kor színvonalán álló tüzoltó-technikai eszközöket és szakmai ismereteket. Emellett azonban a jogi szabályozás fejlesztését is sürgették a magyar tüzoltók. A korabeli magyar tüzoltók kiválóságai tüzrendészeti törvénytervezeteket hoztak létre. ${ }^{11}$ Végül azonban a tüzrendészet átfogó szabályozására nem törvény, hanem rendelet formájában került sor 1888-ban. ${ }^{12}$ (III.sz. melléklet)

A polgári magyar állam időszakában 1888-ban szabályozták először átfogó módon a tüzrendészet témakörét. E szabályozás már három csoportba sorolta a tüzoltóságokat, úgy mint díjazott tüzoltóságokat, önkéntes tüzoltóságokat és köteles tüzoltóságokat. Köteles tüzoltóságokat ott kellett létrehozni, ahol sem díjazott, sem pedig önkéntes tüzoltóság nem működött. E településeken a 20-40 év közötti férfi lakosságból kellett létrehozni a köteles tűzoltóságot. Valamennyi tủzoltóság számára kötelező volt a Magyar Országos Túzoltó Szövetségbe való belépés. A rendelet a különbözö tüzoltó szervezetek számára lehetővé tette az egyenruha és kötelezővé a jelvény viselését, egyben pedig az illetéktelen jelvényviselést pénzbírsággal sújtotta. A tüzoltókat közhatósági jogú személynek nyilvánította. Meghatározta a rendelet továbbá, hogy csak képzett személyzettel rendelkező tüzoltóságok müködhetnek, továbbá, hogy a tüzoltás során megsérült tüzoltók gyógyításáról gondoskodni kell. ${ }^{13}$

A közhatósági jogú személy rendszer a polgári magyar állam sikertörténete volt. Azokat a személyeket nevezték közhatósági jogú személyeknek, akiknek a gondjaira bíztak valamilyen szakterületet és ennek védelme érdekében különleges jogokkal ruházták fel. Ilyenek lehettek például a gátőrök, a vasúti pályaőrök, a vadőrök, az erdőőrök, a halőrök, és a tüzoltók is. A közhatósági jogú személyeknek valamilyen — a szakterületük témájában szerzett és államilag elismert — szakképesítéssel kellett rendelkezniük. Ennek a birtokában kerülhettek be az államigazgatás által vármegyénként szervezett közhatósági tanfolyamra, ha makulátlan erkölcsi állapotot és nemzethü magatartást tudtak bizonyítani. A közhatósági tanfolyam eredményes elvégzése után tehettek esküt. Ennek nyomán váltak jogosulttá a közhatósági munkakörök betöltésére. A közhatósági jogú személyeket nem az állam fizette, hanem az a személy vagy szervezet aki, illetve ami foglalkoztatta, például víztársulatok, vasúti társaságok, erdötulajdonosok stb. A tüzoltók esetében fizetést nyilvánvalóan csak a díjazott tüzoltók kaphattak. ${ }^{14}$

A közhatósági jogú személyeknek joguk volt az általuk észlelt törvénysértéseket megakadályozni, a törvénysértőket elfogni, és eszközeiket elkobozni. E tevékenységük érdekében fegyverhasználati joguk is volt. Egyenruháról és fegyverről az őket foglalkoztatóknak kellett gondoskodni. Azonban nem minden közhatósági jogú személy volt felfegyverezve. A vasúti pályaőrök például a két világháború közötti időszakban nem rendelkeztek szolgálati fegyverrel. Ugyanígy fegyvertelenek voltak a polgári magyar állam teljes időszakában a tủzoltók. Mivel a közhatósági jogú személyek viszonylag kiterjedt hatáskörrel rendelkeztek, ezért szükség volt a közhatósági tanfolyam eredményes elvégzésére, mivel itt sajátíthatták el a közhatósági feladataik eredményes ellátásához szükséges ismereteket. Ezen ismeretek birtokában lehetett tölük megkövetelni a jogszerü müködést. ${ }^{15}$

A tüzoltók tekintetében nyilvánvalóan a tüzrendészeti szabálysértések elleni fellépés alkotta a közhatósági feladataik teljesítését. Különösen tüzoltás esetében volt hasznos a közhatósági jogú besorolásuk, mivel ennek birtokában sokkal eredményesebben és jogszerübben léphettek fel a tủzoltást nehezítő körülmények, illetve személyek ellen. A tüzoltók esetében a közhatósági feladataik ellátásra történő felkészítésük általában a szakmai tanfolyamok során valósult meg.

Az 1888. évi tüzrendészeti rendelet nyomán sor került az egyes részterületek szabályozását megvalósító jogszabályok kialakítására. ${ }^{16}$

A tüzvédelemmel kapcsolatos jogszabályok külön csoportját alkotta a biztosítási csalások elleni fellépés, illetve azok megelőzése. Már az 1870-es években szabályozták, hogy a tüzbiztosító társaságok ügynökeivel nem köthető a biztosított ingó és ingatlan vagyon értékénél magasabb kártérítési összeeggel biztosítás. Rendeletben rögzítették azt is, hogy tüzkár okán az elégett tárgyak forgalmi étékét kell alapul venni, nem pedig azok beszerzési árát. ${ }^{17}$ (IV.sz. melléklet) A tüzbiztosítási szerződésekben rögzített összegek kifizethetöségét pedig úgynevezett ,ártatlansági bizonyítvány”-hoz kötötték. $\mathrm{Az}$,ártatlansági bizonyítvány”-t pedig a területileg illetékes közhatóságnak kellett kiállítania. E hatóság — megfelelö vizsgálat eredményeként — bizonyítványban tanúsította, hogy a tủzbiztosítás kedvezményezettje ártatlan a tüz keletkezésében. ${ }^{18}$ (V.sz. melléklet)

A tủzrendészeti rendelet és a tüzrendészeti részterületek jogszabályok útján megvalósított szabályozása azonban nem szorította háttérbe a szakterület törvényi szabályozásának az igényét. A Magyar Országos Tủzoltó Szövetség 1889-ben felirattal fordult a belügyminiszterhez a tüzrendészeti törvény létrehozása érdekében. ${ }^{19} 1899$-ben a szövetség pályázatot hirdetett a tủzrendészeti törvény megírására. Egyetlen pályamü érkezett BREUER Szilárd tollából. E pályamüvet alakította át a szövetség, majd 
1900-ban küldöttség útján átadta a belügyminiszternek. A törvénytervezet szövegét a szövetség elküldte az országgyűlési képviselőknek és a napilapok szerkesztőségeinek. Az újságok szerkesztőségei vegyes módon fogadták a tüzoltó törvénytervezetet. Volt olyan hírlap, amelyben a törvénytervezetböl részleteket közöltek, de akadtak olyan periodikák is, amelyek kigúnyolták a tűzoltókat. A Magyar Országos Tüzoltó Szövetség a Tüzoltó Közlönyben felhívást tett közzé, amelyben arra kérte a tüzoltókat, hogy olyan képviselőjelöltekre adják le a szavazataikat, akiknek a programjában szerepel a tüzrendészeti törvény létrehozása és a tüzbiztosító társaságok megadóztatása. Végül is a belügyminiszter 1906ban felvette programjába a tüzrendészeti törvény létrehozását. A tervezetet 1907-ben tárgyalták, amely azonban nem vezetett sikerre, ezért 1909-ben a belügyminiszter levette programjáról a tủzrendészet témáját. ${ }^{20}$

A háború és az azt követő zürzavaros időszak nem tette lehetővé a tüzrendészeti törvény témájával az érdemi foglalkozást. 1920-ban azonban a Magyar Országos Tüzoltó Szövetség ismét elővette a tüzrendészeti törvény témáját. A tüzrendészeti törvény ugyan nem jött létre, azonban a belügyminiszter a témát újabb rendeletben szabályozta. ${ }^{21}$ (VI.sz. melléklet)

Az új rendelet számos témakörben az 1888. évi szabályozást követte, azt megerösítve illetve pontosítva. Fontos új elemnek tekinthető a tüzrendészeti hatáskörök meghatározása. Első fokú hatóság volt:

- kis- és nagyközségekben a járási főszolgabíró;

- a rendezett tanácsú városokban a polgármester;

- törvényhatósági jogú városokban a tanács által kijelölt tisztviselö;

- Budapesten a kerületi elöljáró.

Másodfokú hatóság volt:

- kis- és nagyközségekben, valamint a rendezett tanácsú városokban az alispán;

- törvényhatósági jogú városokban és Budapesten a tanács.

Harmadfokú hatóság a belügyminiszter volt. ${ }^{22}$

A belügyminiszteri tüzrendészeti rendelet tette lehetővé a tüzrendészeti felügyelök foglalkoztatását, igaz megengedte azt is, hogy a már alkalmazott tisztviselők közül kérjenek a fel a feladatra egyegy főt, más teendőik végzése mellett. A tűzrendészeti tisztséget betöltőknek azonban el kellett végezniük a Magyar Országos Tüzoltó Szövetség által megrendezett tüzoltó tiszti tanfolyamot, ezzel szerezve meg a tüzoltó tiszti képesítést. A tüzrendészeti előadók azonban nem állami, hanem önkormányzati tisztviselők voltak. A tüzrendészeti felügyelők tüzrendészeti szakközegek voltak. A rendelkezés ennek megfelelően határozta meg a feladataikat. ${ }^{23}$

Az állami és az önkormányzati tisztviselői jog között jelentős különbségek voltak, melyeket a két világháború között fokozatosan számoltak fel oly módon, hogy az önkormányzati tisztviselők helyzetét közelítették a kedvezőbb helyzetben lévő állami tisztviselőkéhez. Az állami tisztviselőket kinevezték és már a dualizmus időszakában nyugdíjképesek voltak. 65 éves korában valamennyi állami tisztviselőnek nyugdíjba kellett vonulnia a szolgálati éveitől függetlenül. Akik azonban hamarabb letöltötték a 40 éves szolgálati viszonyt, azokat a 40. szolgálati évükben nyugdíjazták, mivel 40 éves szolgálat után a nyugdíj összege megegyezett a fizetéssel és senkinek sem lehetett több a nyugdíja, mint a fizetése. Az állami alkalmazottak a lakás és a betegbiztosítás tekintetében is kedvezőbb helyzetben voltak, mint az önkormányzati társaik. Emellett pedig az önkormányzati tisztviselőket eredetileg 6 évre választották. Az önkormányzati tisztviselők hátrányos helyzetét azonban a II. világháború időszakára lényegében felszámolták. ${ }^{24}$

Végül, hosszas huzavona után 1936-ban került sor a magyar tüzrendészeti törvény ${ }^{25}$ és a végrehajtási utasítása létrehozására. ${ }^{26}$

A tüzrendészeti törvény kötelezte a tüzbiztosítókat tüzrendészeti járulék fizetésére, amely a belföldi tüzbiztosítások bevételének $1 \%$-a és $2 \%$-a közötti összege lehetett. A járulék összegét a belügyminiszter - a pénzügyminiszterrel egyetértésben - évente állapította meg és a biztosítóknak az öszszeget $1 / 4$ éves bontásban kellett befizetniük. ${ }^{27}$ (VII.sz. melléklet)

A tüzrendészeti törvény, illetve annak végrehajtási utasítása az ország területét — a honvéd és a csendőr kerületek területi beosztásának megfelelően - 7 tüzrendészeti kerületbe osztotta. Az ország tüzrendészeti teendőit az országos tüzrendészeti felügyelő fogta össze. Alárendeltségébe tartoztak a kerületi tűzrendészeti felügyelők, akik a vármegyei és a törvényhatósági jogú tűzrendészeti felügyelöket irányították. A tüzrendészeti felügyelői rendszerben a legalacsonyabb szintet a járási és a rendezett tanácsú városok tüzrendészeti felügyelői alkották. Ezzel létrejött a magyar állam tüzrendészeti szakhatósági rendszere. A tüzrendészeti felügyelők és a tüzoltó parancsnokok hivatalból tagjai voltak a közigazgatási bizottságoknak. ${ }^{28}$ 
A törvény felhatalmazta az illetékes törvényhatóságokat, hogy a hatósági területükön müködő ipari és mezőgazdasági nagyüzemeket kötelezhessék üzemi tüzoltó szervezetek felállítására.

A korábbi szabályozást továbbfejlesztve a jogszabályok négy féle tüzoltóságot különböztettek meg, úgy mint hivatásos, önkéntes, köteles és magán tűzoltóságokat. A tüzoltóságoknak továbbra is kötelezően elöírták a Magyar Országos Tüzoltó Szövetség-i tagságot. ${ }^{29}$

Az 1936. évi tüzrendészeti törvény ${ }^{30}$, valamint végrehajtási utasítása ${ }^{31}$ volt a polgári magyar állam tüz elleni védekezési rendszerét szabályozó jogszabályoknak a csúcsa, egyben pedig a tűzoltó szervezetek, illetve tüzrendészeti hatóságok szabályozásának is a legfejlettebb formája.

Mindkét jogszabályban nyomot hagyott a háború közelsége, hiszen harctevékenység által sújtott területeken a tüzoltóságokat a területileg illetékes katonai parancsnok ideiglenes átalárendeltségébe helyezte. A II. világháborúval zárult a polgári magyar állam időszaka és annak részeként a polgári magyar tűz elleni védekezés is. Már az Ideiglenes Nemzeti Kormány 1945-ben elrendelte a tủzoltóságok és a tủzrendészet újjászervezését. E témában kibocsátott rendelkezésében pedig, egységes magyar tüzoltóságot állított fel, feloszlatva a Magyar Országos Tủzoltó Szövetséget és az önkéntes tüzoltó testületeket. Felállította az országos és a vármegyei, illetve budapesti tüzoltó-parancsnokságokat. A Tủzbiztosítók által kötelezően befizetendő járulék összegét pedig — a korábbi 1-2 \%-ról — a bevétel $10 \%$-ra növelte. ${ }^{32}$ (VIII.sz. melléklet)

Érdekes körülmény, hogy az Ideiglenes Nemzeti Kormánynak a tüzoltóság és a tüzrendészet újjászervezéséről szóló rendelete hatályon kívül helyezte ugyan az 1936. évi tüzrendészeti törvényt, azonban ennek a végrehajtási utasításáról nem rendelkezett. A végrehajtási utasítást így csak 1957-ben hatálytalanították. ${ }^{33}$

A korábban ismeretlen kinevezéseken nyugvó parancsnoki rendszer elősegítette a régi vezetők és szakemberek kiszorítását, helyükre pedig, a Kommunisták Magyarországi Pártjának, majd a Magyar Kommunisták Pártjának szimpatizánsai kerülhettek, akik általában a kellő szakmai hozzáértés hiányával küszködtek. Ez a helyzet nem csupán a tüzoltóságot jellemezte ebben az időben, hanem a teljes magyar rendvédelmet. A Magyar Királyi Rendőrség helyébe lépő Magyar Államrendőrség új tisztjeinek döntő többsége például még érettségivel sem rendelkezett, szemben a régi tisztekkel, akik jogakadémiai végzettséggel vagy jogtudori diplomával rendelkeztek. ${ }^{34}$

A korábbi törvények rendeleti úton történő hatálytalanítása sem tekinthető egyedi, csupán a magyar tüzoltóságot súlytó cselekedetnek. A Magyar Királyi Csendőrséget például ugyancsak rendeleti úton számolta fel az ideiglenes nemzeti kormány ${ }^{35}$, holott a testületet a legitim magyar országgyülés 1881-ben hozta létre. ${ }^{36}$

A polgári magyar állam tűzoltóságainak a pártállam tủzoltóságába vezető átmeneti időszaka 1948ban zárult. Ekkor kormányrendelet formájában szabályozták a témakört a tüzvédelmi szervezetek teljes államosításával. Ekkor került megszüntetésre a városi és üzemi tüzoltóságok formájában még meglévő széttagoltság, ezzel megteremtve az egységes állami tüzoltóságot. Rendeleti úton újraszabályozták a tüzrendészeti és a tüzoltási feladatokat, a hatásköröket, a szervezeteket, a kapcsolódó szabálysértések tényállásait. ${ }^{37}$ (IX.sz. melléklet) A polgári magyar állam tủzoltósági törvényének 1945. évi hatálytalanítása után 12 évvel később került sor a pártállam keretei között az első tűzoltósági törvény létrehozására 1956-ban, amelyet általában tủzrendészeti kódex néven emlegettek. ${ }^{38}$

Összességében megállapítható, hogy a polgári magyar állam tủzoltósági modellje sokkal szélesebb társadalmi alapokon nyugodott, mint a pártállami modell és a polgári modell részét alkották a társadalmi szerveződések, a választási szisztéma, amit a pártállami struktúra nélkülözött. Kétségtelen tény azonban, hogy az államosítás nyomán a szakterület anyagi ellátásának a biztonsága gyarapodott. A több évtized során kifejlesztett polgári modell jól megállta a helyét még a háborús körülmények között is. Vitathatatlan erényei ellenére azonban tökéletesen alkalmatlan volt arra, hogy a pártállam viszonyai között müködjön. A magyar polgári tüzvédelmi modell pártállamba integrálhatatlanságából fakadóan e modellt megszüntették, helyette pedig a szovjet tüzvédelmi szisztémát adaptálták Magyarországon.

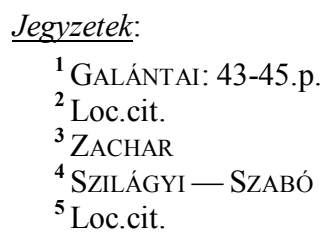


${ }^{6}$ Aradon már 1835-ben létrejött az „Első Önkéntes Polgári Tűzoltókör”, melynek alapszabályzatát a Nagyváradi Császári Királyi Helytartósági Osztály 1861-ben hagyta jóvá. Az első üzemi tủzoltóságot pedig, 1855-ben az Óbudai Hajógyárban hozták létre.

${ }^{7} 1872$ /VIII.tc.

8 1870-ben Budapesten, 1878-ban Debrecenben, 1880-ban Kecskeméten, 1886-ban Pécset hoztak létre hivatásos személyi állománnyal rendelkező tűzoltóságot.

${ }^{9} 3365 / 1869$. (VI.17.) BM.kl.

1053 720/1878.BM.kr.

${ }^{11}$ Dr. LinDNER Gusztáv 1876-ra, a Magyar Országos Tüzoltó Szövetség választmánya 1883-ra, Rösch Frigyes és dr. HAUER Gyula 1885-re tüzrendészeti -törvénytervezeteket hoztak lére, melyeket eljuttattak a belügyi tárcához, illetve az 1883. évi tervezetet közzé tették a Tüzoltó Közlöny 1884 októberi számában is.

RONCSIK: 430-435.p.

1253 888/1888.BM.kr.

${ }^{13}$ Loc.cit.

${ }^{14}$ PARÁdi Ákos ; PARÁdi Ákos — PARÁdi József

15 PARÁDi Ákos: op.cit.

${ }^{16}$ Rendeleti úton szabályozták a tüzoltó szerek hazai cégektől történő kizárólagos beszerzését, a felszerelések szabványosítását, a tüzoltó szerek vasúti szállításának kedvezményessé tételét, a tüzoltó tanfolyamokat stb.

${ }^{17} 49$ 925/1882.BM.r.

1832 706/1882.BM.kr.

${ }^{19}$ RONCSIK: op.cit. 439.p.

${ }^{20}$ Loc.cit. 142-145.p.

21230 000/1925.BM.r.

${ }^{22}$ Loc.cit.

${ }^{23}$ Loc.cit.

${ }^{24}$ PARÁDI József: A magyar rendvédelem személyi állományának szociális viszonyai 1867-1945. ; PARÁDI József: A polgári magyar állam rendvédelmi testületeinek humán viszonyai 1867-1945.

25 1936/X.tc.

26180 000/1936.BM.r.

${ }^{27} 1936 /$ X.tc. : op.cit.

${ }^{28}$ Loc.cit.

${ }^{29}$ Loc.cit.

${ }^{30}$ Loc.cit.

31 180 000/1936.BM.r. : op.cit.

32 10 280/1945.ME.r.

${ }^{33}$ A hatálytalanítást a tűzoltóságokról és a tűzrendészetről szóló 1956/13.tvr. végrehajtásáról szóló 4/1957 (XI.19.) BM.r. írta elö.

${ }^{34}$ PARÁDI József: Rendvédelmi tisztképzésünk hagyományai. ; PARÁDI József: Rendvédelmünk képzési és képesítési rendszere 1867-1945. ; PARÁDI József: A magyar rendőrtisztképzés tradíciói 1867-1945. ; PARÁDI József: A polgári magyar állam rendvédelmi testületeinek humán viszonyai 1867-1945. : op.cit.

${ }^{35}$ 1690/1945.ME.r. ; PARÁDI József: A Magyar Királyi Csendörség. Az elsö magyar polgári, központositott közbiztonsági örtestület 1881-1945. ; PARÁDI József: A polgári magyar állam első központosított közbiztonsági szerve a Magyar Királyi Csendőrség. ; PARÁDI József: A Magyar Királyi Csendőrség megalakulása és müködése 1881-1918.

${ }^{36} 1881 /$ III.tc.

${ }^{37}$ 5090/1948. (V.13.) korm.r.

38 1956/13.tvr. a tüzoltóságról és a tűzrendészetről.

Jegyzetekben alkalmazott röviditések:

\section{MONOGRÁFIÁK, KISMONOGRÁFIÁK ÉS HASONLÓ JELLEGÜ KÖTETEK}

GALÁNTAI

PARÁDI Ákos — PARÁDI József

PARÁdi József: A Magyar Királyi Csendörség. Az első magyar polgári, központositott közbiztonsági örtestület 1881-1945.

RONCSIK

SZILÁGYI - SZABÓ
GALÁnTAI József: A Habsburg-monarchia alkonya. Osztrák-magyar dualizmus 1867-1918. Budapest, 1985, Kossuth. 386 p. HU-ISBN 9630925893.

- PARÁdi Ákos — PARÁDI József: Rendvédelmünk 1867-1945. Budapest, 2006, Rendőrtiszti Főiskola. HU-ISBN 9630602814.

PARÁDi József: A Magyar Királyi Csendőrség. Az első magyar polgári, központositott közbiztonsági örtestület 1881-1945. Budapest, 2012, Szemere Bertalan Magyar Rendvédelem-történeti Tudományos Társaság. 281 p. HUISBN 978963084794 0. /A magyar rendvédelem-történet öröksége, 2./ HUISSN 2062-8447.

- Roncsik Jenő: A Magyar Országos Tüzoltó Szövetség hatvanéves története 1870-1930. Debrecen, 1935, Városi Nyomda. 550 p.

- SzILÁgyi János — Szabó Károly: A tüzrendészet fejlödése az őskortól a modern időkig. Budapest, 1986, Budapest-Kecskemét, BM Kiadó. 387 p. HU-ISBN 9637703136. 


\section{TANULMÁNYOK}

PARÁdi Ákos

PARÁDI József: A polgári magyar állam első központosított közbiztonsági szerve a Magyar Királyi Csendőrség.

PARÁDI József: Rendvédelmi tisztkép-

PARÁDI József: A Magyar Királyi Csendőrség megalakulása és müködése 1881-1918. si és képesítési rendszere 1867-1945.

PARÁDI József: A magyar rendőrtisztképzés tradíciói 1867-1945.

PARÁDI József: A magyar rendvédelem személyi állományának szociális viszonyai 1867-1945.

PARÁDI József: A polgári magyar állam rendvédelmi testületeinek humán viszonyai 1867-1945. zésünk hagyományai

PARÁDI József: Rendvédelmünk képzé-

PARÁDI Ákos: A magyar rendvédelem civil szerveződései 1867-1945. Rendvédelem-történeti Füzetek (Acta Historiae Preasidii Ordinis), XV. évf. (2008) 18. sz. 28-51. p. HU-ISSN 1216-6774. A tanulmány korábbi változata 2004. október 13-án, Budapesten hangzott el a Szemere Bertalan Magyar Rendvédelem-történeti Tudományos Társaság által szervezett rendvédelemtörténeti tudományos konferenciasorozatnak „Karhatalmi feladatok a bünmegelözés és a békefenntartás szolgálatában Európában a XIX-XX. században." című XVIII. konferenciáján. A publikált tanulmány az előadás javított, bővített és átdolgozott változata.

PARÁDI József: A polgári magyar állam első központosított közbiztonsági szerve a Magyar Királyi Csendőrség. Belügyi Szemle, XXXVII.évf. (1989) 2.sz. 35-40.p. HU-ISSN 0017-6540.

PARÁDI József: Rendvédelmi tisztképzésünk hagyományai. Belügyi Szemle, XXXV.évf. (1997) 4.sz. 101-109.p. HU-ISSN 1218-8956.

PARÁDI József: A Magyar Királyi Csendőrség megalakulása és müködése 1881-1918. Rendvédelem-történeti Füzetek (Acta Historiae Preasidii Ordinis), VII.évf. (1997) 8.sz. 78-83.p. HU-ISSN 1216-6774. A tanulmány korábbi változata 1996. október 29-én, Budapesten hangzott el a Szemere Bertalan Magyar Rendvédelem-történeti Tudományos Társaság által szervezett rendvédelem-történeti tudományos konferenciasorozatnak „A napóleoni közbiztonsági örtestület útja Párizstól - Itálián és Ausztrián keresztül — Budapestig. " című VIII. konferenciáján. A publikált tanulmány az előadás javított, bővített és átdolgozott változata.

PARÁDI József: Rendvédelmünk képzési és képesítési rendszere 1867-1945. Rendvédelem-történeti Füzetek (Acta Historiae Preasidii Ordinis), XIII.évf. (2007) 16.sz. 90-93.p. HU-ISSN 1216-6774. A tanulmány korábbi változata 2002. november 12-én, Budapesten hangzott el a Szemere Bertalan Magyar Rendvédelem-történeti Tudományos Társaság által szervezett rendvédelemtörténeti tudományos konferenciasorozatnak „A rendvédelmi szakképzés története." című XVI. konferenciáján. A publikált tanulmány az előadás javított, bővített és átdolgozott változata.

PARÁDI József: A magyar rendőrtisztképzés tradíciói 1867-1945. Rendvédelem-történeti Füzetek (Acta Historiae Preasidii Ordinis), XIII.évf. (2007) 16.sz. 94-99.p. HU-ISSN 1216-6774. A tanulmány korábbi változata2002. november 12-én, Budapesten hangzott el a Szemere Bertalan Magyar Rendvédelem-történeti Tudományos Társaság által szervezett rendvédelemtörténeti tudományos konferenciasorozatnak ,A rendvédelmi szakképzés története." című XVI. konferenciáján. A publikált tanulmány az előadás javított, bővített és átdolgozott változata.

PARÁDI József: A magyar rendvédelem személyi állományának szociális viszonyai 1867-1945. Rendvédelem-történeti Füzetek (Acta Historiae Preasidii Ordinis), XIV.évf. (2008) 17.sz. 57-64.p. HU-ISSN 1216-6774. A tanulmány korábbi változata 2003. november 11-én, Budapesten hangzott el a Szemere Bertalan Magyar Rendvédelem-történeti Tudományos Társaság által szervezett rendvédelem-történeti tudományos konferenciasorozatnak „A rendvédelem humán viszonyai." című XVII. konferenciáján. A publikált tanulmány az előadás javított, bővített és átdolgozott változata.

PARÁDI József: A polgári magyar állam rendvédelmi testületeinek humán viszonyai 1867-1945. Rendvédelem-történeti Füzetek (Acta Historiae Preasidii Ordinis), XIX.évf. (2010) 22.sz. 92-114.p. HU-ISSN 1216-6774. A tanulmány korábbi változata 2008. október 10-én, Budapesten hangzott el a Szemere Bertalan Magyar Rendvédelem-történeti Tudományos Társaság által szervezett rendvédelem-történeti tudományos konferenciasorozatnak „,Másfél évszázad rendszerváltozásainak hatásai nemzeti rendvédelmünkre." címü XXII. konferenciáján. A publikált tanulmány az előadás javított, bővített és átdolgozott változata.

ZACHAR
ZACHAR József: Fejezetek az osztrák csendőrség történetéből. Rendvédelemtörténeti Füzetek (Acta Historiae Preasidii Ordinis), VII.évf. (1997) 8.sz. 105109.p. HU-ISSN 1216-6774. A tanulmány korábbi változata 1996. október 29-én, Budapesten hangzott el a Szemere Bertalan Magyar Rendvédelem-történeti Tudományos Társaság által szervezett rendvédelem-történeti tudományos konferenciasorozatnak „A napóleoni közbiztonsági örtestület útja Párizstól - Itálián és Ausztrián keresztül - Budapestig." címü VIII. konferenciáján. A publikált tanulmány az előadás javított, bővített és átdolgozott változata. 


\section{JOGSZABÁLYOK}

1872/VIII.tc.

1881/III.tc.

1936/X.tc.

53 720/1878.BM.kr.

49 925/1882.BM.r.

32 706/1882.BM.kr.

53 888/1888.BM.kr.

230 000/1925.BM.r.

180 000/1936.BM.r.

10 280/1945.ME.r.

1690/1945. (V.7.) ME.r.

5090/1948. (V.13.) korm.r.

1872/VIII.tc. az ipartörvény.

- 1881/III.tc. a közbiztonsági szolgálat szervezéséröl.

- 1936/X.tc. a tüzrendészet fejlesztéséröl.

— $\quad 53$ 720/1878.BM.kr. az országos tüzoltó szövetség központi választmányának szakközegül elismerése tárgyában. Magyarországi Rendeletek Tára, XII.évf. (1878) II. füzet. 50-51.p.

- 49 925/1882.BM.r. az öngyújtogatásra csábító túlbiztosítások meggátlása. Magyarországi Rendeletek Tára, XVI.évf. (1882) I. füzet. 1125-1483.p.

— $\quad 32$ 706/1882.BM.kr. tüzesetek alkalmazásának, a tüz támadásának közvetlen okai iránt felveendő jegyzőkönyvek és azok alapján kiállítandó úgynevezett ,ártatlansági bizonyítványok” ügyében.

Magyarországi Rendeletek Tára, XVI.évf. (1882) I. füzet. 1123-1124.p.

- $\quad 53$ 888/1888.BM.kr. tüzrendészeti kormányrendelet kibocsátása tárgyában. Magyarországi Rendeletek Tára, XXII.évf. (1888) I. füzet. 1127-1128.p.

- $\quad 230$ 000/1925.BM.r. a tüzrendészetről alkotott 53 888/1888.BM.kr. kiegészítéséről, módosításáról és végrehajtásáról. Magyarországi Rendeletek Tára, XXXIX.évf. (1925) I. füzet. 249-258.p.

- $\quad 180$ 000/1936.BM.r. a tűzrendészet újabb szabályozásáról. Magyarországi Rendeletek Tára, XLVIII.évf. (1936) II. füzet. 789-920.p.

- $\quad 10$ 280/1945.ME.r. a tűzoltóság és a tűzrendészet újjászervezéséről. Magyarországi Rendeletek Tára, LIX.évf. (1945) I. füzet. 901-904.p.

- 1690/1945. (V.7.) ME.r. a csendőrség feloszlatásáról és az államrendőrség megszervezéséröl. Magyarországi Rendeletek Tára, LXXIX.évf. (1945) I-VI. füzet. 131-133.p.

— 5090/1948. (V.13.) korm.r. az állami tüzoltóság szervezése és a tűzoltóság szervezete tárgyában.

1956/13.tvr.

3365/1869. (VI.17.) BM.kl.

- 1956/13.tvr. a tüzoltóságról és a tüzrendészetről.

— 3365/1869. (VI.17.) BM.kl. a Magyar és Erdélyország összes törvényhatóságához a tüzrendészeti szabályok kezelése iránt.

\section{Mellékletek jegyzéke:}

I.sz.melléklet

3365/1869.BM.kl. a Magyar- és Erdélyország ország összes törvényhatóságaihoz, a tűzrendészeti szabályok kezelése iránt.

II.sz.melléklet

53 720/1878.BM.r. az Országos Tủzoltó Szövetség központi választmányának szakközegül elismerése tárgyában.

III.sz.melléklet

53 888/1888.BM.kr. tüzrendészet kormányrendelet kibocsátása tárgyában .

IV.sz.melléklet

49 925/1882.BM.kr. az öngyújtogatásra csábító túlbiztosítások meggátlása tárgyában.

V.sz.melléklet

32 706/1882.BM.kr. tüzesetek alkalmával a tüz támadásának közvetlen okai iránt felveendő jegyzőkönyvek és azok alapján kiállítandó úgynevezett „ártatlansági bizonyítványok” ügyében.

VI.sz.melléklet

230 000/1925.BM.kr. a tűzrendészetről alkotott 53 888/1988.BM.r. kiegészítése, módosítása és végrehajtása tárgyában.

VII.sz.melléklet

1936/X.tc. a tüzrendészet fejlesztéséröl.

VIII.sz.melléklet

10 280/1945.ME.r. a tüzoltóság ás a tüzrendészet újjászervezéséről.

IX.sz.melléklet

5090/1948.korm.r. az állami tűzoltóság szervezése és a tűzoltóság szervezete tárgyában. 
3365/1869.BM.kl.

I.sz.melléklet

a Magyar- és Erdélyország ország összes törvényhatóságaihoz, a tüzrendészeti szabályok kezelése iránt.

A tüzvész-esetek tapasztalás szerint a takarítás és cséplés idején leggyakoriabbak, s akkor egyszersmind legveszedelmesebbek és legkárosabbak is, mert a behordott takarmány és élet a tüz terjedésének bő anyagot szolgáltatván, a tüz nehezen oltható, s így sokszor egész községek, a lakosság összes termesztményeivel együtt, a tüz martalékául esnek.

Ily károk lehető elhárítása végett felhívom a törvényhatóságokat, hogy a tüzrendészeti szabályok szigorú kezelése iránt területeiken, a helyi körülmények szerint, czélszerüen és erélyesen intézkedjenek.

Különösen intézkedés teendö:

1. Hogy a takarmány és termesztmények összehalmozása a házak közt lehetőleg korlátoltassék, s a községek azok tartására, mennyiben ez kivihetö, inkább a községen kívül jelöljenek ki alkalmas helyeket, s a cséplés és nyomtatás lehetöleg szintén künn eszközöltessék.

2. Hogy a takarmány és élet behordásánál csürökben, csűrkertekben, szérükön, istállókban, padlásokon s általában könynyen gyúló anyagok közelében a dohányzás, nyílt-világgal való járás, lövöldözés, tüzelés és bármily tüzelő szerek használata szigorúan megtíltassék, a gyufák és más tüzelő szerek a gyermekek elől gondosan őriztessenek, és tüzveszélyes gyermeki játékszerek használata általában meg ne engedtessék.

3. Hogy a szükséges tüzoltó szerek, hol nincsenek, a községek által lehetőleg megszereztessenek, és a meglevők folyvást jó karban tartassanak.

4. Hogy minden háznál, csürnél, szérünél s a takarmány és élet más rakhelyén a megkívántató mennyiségü víz, a tüzoltáshoz szükséges házi eszközökkel folyvást készen tartassék.

5. Hogy a kémények rendesen tisztíttassanak.

6. Hogy a csavargók, kik nem ritkán okai a tüzvésznek, szemmel tartassanak, és illetőségük helyére eltolonczoztassanak.

7. Hogy minden helységben a helyi viszonyoknak megfelelő tüzőrség szerveztessék, s ott, hol az kivihető, tüzoltóegyletek létesíttessenek.

8. Hogy a lakosság a tűzkár elleni biztosítás üdvös voltáról felvilágosíttassék, s vagyonának biztosítására erélyesen buzdíttassék.

9. Hogy az építkezéseknél a tüzrendőri szabályok megtartassanak, és a nép minden alkalommal lehetőleg szilárd, kevésbé tüzveszélyes anyagokkal való építkezésre serkentessék.

10. Hogy a községi elöljárók, netaláni tüzvész esetére, a tüzoltásnak észszerü intézésére személyesen köteleztessenek, kijelentetvén, hogy az elöljáró ebbeli intézkedéseinek büntetés terhe alatt mindenki engedelmeskedni tartozik.

11. Minden tüzeset után, a tüztámadás okának lehető kinyomozása végett, a helyszínén vizsgálat teendő, $\mathrm{s}$ a tüzvész vétkes okozóinak törvényszerü megfenyítése eszközlendő.

12. Gyújtogatások észlelése esetében, a gyújtogatok ellen rendelendő rögtönbíráskodás engedélyezése végett a belügyministeriumhoz azonnal jelentés teendő.

Budán, 1869. évi június-hó 17-én.

II.sz.melléklet

\section{720/1878. BM.r.}

az Országos Tüzoltó Szövetség központi választmányának szakközegül elismerése tárgyában.

Az országos tüzoltószövetség központi választmányának hozzám intézett folyamodványa folytán, melyben közczéljainak elömozdítására, különösen pedig a központi választmány ügyviteli költségeinek részbeni fedezésére anyagi és erkölcsi támogatás, egyszersmind pedig szakközegül való elismerését kéri, figyelembe véve ezen közegnek a nemzetgazdasági és közbiztonsági tekintetben messze kiható jelentőséggel bíró tüzoltói intézmény terjesztésére és annak ugyanazonos és helyes elvek szerint való fejlesztésére irányzott üdvös hatását és czélszerüségét, a jelen számú és keltủ rendeletemmel az orsz. tűzoltószövetség központi választmányát tüzoltó ügyekben illetékes szakközegül ismertem el, és felhívom a vármegye, város közönségét is, hogy valahányszor ily ügyekben szakvéleményre van szüksége, az iránt közvetlenül a nevezett országos tűzoltószövetségnek központi választmányához forduljon.

Minthogy továbbá az országos tűzoltó-szövetség gyarapodása és felvirágzása a hazai tűzoltóegyletek buzgó támogatásától függ, felhívom a törvényhatságot, hogy a területén levő tủzoltó egyleteket fennebbiekröl értesítvén, és az ily irányú társulás fontosságáról és szükségességéröl meggyőzvén, azokat a szövetséghez való csatlakozásra hívja fel.

Budapesten, 1878. évi február hó 5-én.

Tisza s.k.

Forrás ! Magyarországi Rendeletek Tára, XII.évf. (1878) II. füzet. 50-51.p. 
$53888 / 1888 . B M . k r$.

III.sz.melléklet

\section{tüzrendészet kormányrendelet kibocsátása tárgyában.}

A tüzvész-statisztikának megdöbbentő adatai, a tüzvészek által okozott jelentékeny károk úgy a humanizmus, mint a nemzet közgazdasági érdekeinek szempontjából elodázhatlan kötelességemmé tették, hogy a magam részéröl jelen tüzrendészeti kormányrendelet kibocsátásával a bajon lehetőleg segíteni igyekezzem. E kormányrendelet - melyhez függelékként minden a tüzrendészetre vonatkozó törvényszakasz és szabályrendeleti pont csatolva lőn égető szükségnek felel meg, s hivatva van több régóta és különféle oldalról hangoztatott eszméket az elmélet teréről a köz- és magánjó valódi érdekében a gyakorlati életbe átvinni.

De ha a legüdvösebb kormányrendeletektől általában csak akkor várható igazi eredmény, ha azok végrehajtásához az arra hivatottak jóakarattal és a kellő ügybuzgalommal járulnak, úgy jelen szabályrendelet is csak akkor teremti meg a várt eredményt, ha a törvényhatóságok és közegeik híven megteszik előirt kötelességeiket.

Jelen szabályrendelet életbelépésénél kiválóan számítok a törvényhatóságok és érdekelt közegeknek hazafias és lelkiismeretes buzgóságára, s a legszigorúbb felügyelettel leszek, hogy a rendelet intézkedései kifogástalanul foganatosíttassanak.

Feleslegesnek tartván a törvényhatóságok figyelmét a szabályozni szándékolt kérdés fontosságára bővebben felhívni, és a kormányrendelet egyes §-ainak bővebb magyarázgatásába bocsátkozni, csupán azt az egyetlen intézkedést emelem itt ki különösen, hogy a szabályrendelet szerint minden községnek kell tủzoltósággal bírnia, s egyszerủen felhívom a törvényhatóságot, hogy a mellékelt tűzrendészeti kormányrendeletnek mihamarabb életbeléptetéséről haladéktalanul gondoskodjék, illetőleg tegye meg az életbeléptetéshez szükséges intézkedéseket. Elvárom különösen, hogy a kormányrendeletnek a jelen rendelet vételét követő legközelebbi közgyülésen tárgyaltatásáról gondoskodjék, s a czélirányos cselekvési programot állapítsa meg, miről is hozzám a közgyülést követő 14 nap alatt külön jelentés teendö, valamint itt is különösen hangsúlyozom, hogy a szabályrendelet 33 . §-a értelmében a tett intézkedések tényleges eredményéről hozzám a folyó 1888 . évi deczember hó 15 -ig okvetlenül tüzetes jelentés teendő.

A kérdéses tüzrendészeti kormányrendelet ... példányban ide mellékelve, a rendezett tanácsú városok és szolgabírói járásoknak a kellő számú példányokkal ellátása végett a törvényhatóság rendelkezésére bocsáttatik.

Kelt Budapesten, 1888. évi augusztus hó 12-én.

\section{B. Orczy Béla, s. $k$.}

\section{FEJEZET}

Általános határozatok

A tűzrendészet azon szabályok összessége, melyek czélja a tűzvész kitörését megakadályozni, $\mathrm{s}$ ha az mindamellett kitört, azt lehetőleg mielöbb eloltani. Az intézkedések tehát első sorban megelőzők, másodsorban pedig a gyors és sikeres oltásra vonatkozók. Az előbbiekhez, a megelőző tüzrendészethez tartoznak:

a, a helyi viszonyoknak megfelelő, czélszerü építési rendszabályok, illetve szabályrendeletek, különös tekintettel az építési anyagra, a tüzelö helyekre, kéményekre, és

b, a tüzveszélyes tárgyak iránti intézkedések.

A másodikhoz, a tủzoltói részhez tartoznak azon megállapodások, melyek:

a, köz- és magán-tüzoltási szerek beszerzésére, mindenkor akadálytalan készentartására, s azoknak mikénti helyes használatára és alkalmazására, továbbá

b, egy tüzoltói rendnek megállapitására s ezzel kapcsolatban jól rendezett, szakszerü tüzoltói és mentői intézménynek (tüzoltóság) létesítésére vonatkoznak.

\section{2. $\S$}

A tűzrendészetet a község kezeli (1886: XXII. t. -ez. 21. §. g/ pontja és 22. §). E ezélból a helyi viszonyoknak megfelelő szabályrendeletet alkotni köteles; és pedig kis- és nagy községek, továbbá rendezett tanácsú városok az 1886. évi XXII. t.-cz. 21. §. al pontja, továbbá 27. és 28. §-ai, törvényhatósági joggal felruházott városok pedig az 1886. évi XXI.t.- cz. 3., 27. és 28. §-ai értelmében.

Ha ezen szabályrendeletekben kihágások minősítésénél büntető határozatok állapíttatnak meg, az csak az 1879. évi XL. t.-cz. vonatkozó szabványainak megtartásával történhetik. Ily kihágásokat ezen törvény értelmében kis- és nagyközségek nem állapíthatnak meg; a szabályrendelet a vármegye által alkotandó.

\section{4. §.}

Ily szabályrendeletek alkotásánál, valamint a tüzrendészetre vonatkozó mindennemű hatósági intézkedésnél úgy a törvényhatóságok, valamint a községek a magyar országos tủzoltó szövetség központi választmányának - melynek székhelye Budapesten van, s mely ily ügyekben a Belügyminisztériumnak is szakközege - útbaigazító szakvéleményét igénybe vehetik, a igen kívánatos, hogy igénybe vegyék. (Belügyministeri körrendelet II/5. 1887. 53,720.sz. Lásd Rendeletek Tára 1878. 50. old.)

\section{FEJEZET}

Megelöző tüzrendészet

5. $\S$.

Tűzvész kitörése és terjedése ellen legbiztosabb óvszer lévén a helyi viszonyokhoz mért jó és szilárd építkezés addig is, míg ez irányban törvény útján történhetik gondoskodás, megfelelő építkezési szabályrendelet alkotandó.

Rendezett tanácsú és törvényhatósági joggal bíró városok ezt a törvény (1886: XXII.) keretén belül és az ott megjelölt alakiságok megtartása mellett önmaguk tehetik. 
Kis és nagyközségekre nézve, melyeknek az építészeti rendészet nem tartozik hatáskörükbe, e tekintetben a vármegye törvényhatósága tartozik gondoskodni.

6. $\S$.

A megelőző tủzrendészethez tartoznak azok is, mik az 1869. évi június 17-én 3.365. sz. a. (Rend. Tára 715. oldal) kelt belügyministeri körrendeletben kötelezőleg megállapíttattak, azonban azon megjegyzéssel, hogy a kéményseprés tekintetében most már azon szabályrendeletek irányadók, melyeket az 1884: XVII. t. - czikk (ipartörvény) 11., 12., és 16. §-ai alapján a törvényhatóságok és rendezett tanácsú városok a törvényes formák megtartásával alkottak, illetve alkotni tartoznak.

\section{7. $\S$}

A vízkészletről való gondoskodás egy fontossága a megelőző tüzrendészetnek. E végből azon községekben, hol az oltáshoz szükséges vízmennyiség természetes tartályokban nem találtatik, kötelessége minden községi elöljáróságnak legalább egy bő tartalmú kút készíttetéséről és fenntartásáról gondoskodni. Nagyobb községek czélirányosan elosztott több hasonló kúttal látandók el.

Ott, hol kutak a helyi viszonyoknál fogva nem létesíthetők medencze, vízfogók vagy úsztatok (zúgok) építendők, melyek évenkint legalább egyszer gyökeresen kitakarítandók.

Nagyobb építkezésekhez adott építkezési engedélyeknél kút építése kötelező feltételül tűzendő. Ezen kutak oly helyre építendők, hogy tüz esetében könnyen hozzáférhetők legyenek.

Tüzvész esetében a telkén fekvő vizet a tüzoltástól senki meg nem vonhatja.

\section{8.}

Ide tartozik végre a megfelelő tűzoltószereknek készletben tartása.

Erre vonatkozólag a következők rendeltetnek:

Minden, legalább 50 házból álló község köteles következő tüzoltó szereket beszerezni s azokat biztos, ezélra készült helyen jó karban fenntartani:

1. Egy szívó fecskendőt, legalább $10 \mathrm{~cm}$ átmérőjü széles henger- és $60 \mathrm{~m}$ tömlővel.

2. Egy vízhordó kocsit 3 hl. hordó és 1 hl. káddal.

3. Két tüzlétrát.

4. Két csákányt.

5. Két tüzhorgot.

6. Két fejszét.

7. Négy vasvillát.

8. Két lámpást.

Még kisebb községek, valamint nagyobb építmények birtokosai targoncza- vagy puttonyfecskendők tartására köteleztetnek.

Minden ház ellátandó a kellő tűzoltó szerrel, melynek mennyiségét és minőségét a helyi tüzoltó-szabvány állapítja meg s azoknak meg- és mibenléte a tüzszemle alkalmával ellenőriztetik.

A községek részéről beszerzendő szívó fecskendők a magyar országos csavarral látandók el. A létező fecskendők ezen rendelet életbeléptétöl számítandó egy év alatt, ha hengerüregük 10 vagy több centiméter, a magyar országos egységes csavarra idomítandók át.

\section{9. $\S$}

Általában tüzvészt okozható tiltott cselekmények vagy mulasztások azonnal meggátolandók, s a mennyiben elbírálásuk a községi elöljáróság hatáskörébe nem tartoznék, az illetékes hatóságnak azonnal bejelentendök.

10. $\S$

Végre a helyhatóság saját kiküldöttei által a tüzoltó-parancsnokság közbejöttével a körülményekhez képest többször, de legkevesebb kétszer egy évben általános tüzvizsgálatot tart, a tüzveszélyes bajok elhárítását szükség esetében az illetőnek költségére elrendeli, s eszközli a háztulajdonosok által tartani kötelezett oltószerek, vízkészlet meglétét s jókarban tartását, a kémények tiszta voltát ellenőrzi. Eljárásáról külön jegyzőkönyvet vezet, melyet esetről esetre a felügyeletet gyakorló tüzoltóparancsnoknak betekintés végett bemutatni köteles.

\section{FEJEZET \\ Tüzjelzés}

11. $\S$

Ki a községben kitört tüzet, vagy tüzveszélyt észreveszi, köteles azt azonnal köztudomásra hozni.

12. .

A más községben észrevett tüzet tartozik az észrevevő tartózkodási helye bírájának (polgármesternek) vagy a rendőrségnek és a tüzoltóságnak haladéktalanul jelenteni.

13. §.

A községi bíró (polgármester) köteles a szabályszerü rendelkezéseket megtenni s intézkedni, hogy a tüzvész kitörésének híre úgy helyben, mint - ha az szükséges - a szomszéd községben lehető gyorsan elterjedjen, utóbbi esetben lehetőség szerint lovas tűzjelentők által. A főszolgabíró is azonnal értesítendő, ki — ha lehetséges - a tüzvész helyén megjelenni köteles.

A tüzriadó a helybeli viszonyok szerint rendezendő.

14. §. 


\section{FEJEZET}

Tüzoltás

15..

A keletkezésben levő vagy már kitört tüzvész elfojtását az erre megalakult tüzoltóság eszközli.

A tüzoltóság, vagy:

a, rendszeres szakszerü, díjazott tüzoltóság, melyet a község saját költségére, mint községi intézményt ezélra tart s rendszeres vezénylet alatt minden szükségessel ellát, vagy

b, önkéntes tüzoltóság, mely egyleti alapon önkéntesen szervezkedik s alapszabályai szerint ugyanazon szolgálatot teljesiti, mint a díjazott tüzoltóság, végre

c, községi (köteles) tüzoltóság, melyet oly kisebb községek, melyek az a.) és b.) pontban említett tüzoltóságot felállítani nem képesek, saját tüzrendészed, illetve tüzoltási rendszabályuk szerint létesíteni kötelesek; megjegyeztetvén, hogy ilynemü köteles tüzoltóságnak minden, bármily kis községben, a vármegye által meghatározandó, egy évet azonban meg nem haladható idő alatt létesülnie kellene, melynek vezetéséröl a községi elöljáróság gondoskodni tartozik.

16..

Díjazott tüzoltóságot az azzal járó tetemes költségnél fogva, föleg csak törvényhatósági joggal felruházott, vagy rendezett tanácsú városok állíthatnak fel s a szükséges költségekről saját háztartásukban költségvetésileg gondoskodnak, felhasználhatván esetleg rendelkezésükre álló más forrásokat is.

17. .

A tüzoltóság legkönnyebben alkalmazható s a községekre nézve a legkevesebb költséggel járó neme az önkéntes tüzoltó intézmény. A törvényhatóságoknak s a föszolgabíráknak magasztos feladata úgy hivatalos, valamint társadalmi úton odahatni, hogy ezen intézmény - a hol csak lehetséges - létesüljön.

Minden községben, melyben legalább 25 alkalmas férfi egyén ajánlkozik, az önkéntes tűzoltóegylet az eleve elkészült alapszabályok szerint megalakítható. E tekintetben ismételten figyelmeztetem a törvényhatóságot, hogy a magyar országos tüzoltó-szövetség központi választmánya kész minden lehető útbaigazítást megadni.

Az önkéntes tüzoltóság rendszerint alapszabályszerü járulékaiból önmagát tartja fenn. Ott azonban, hol az szükséges, a költségekhez a község is hozzájárul esetről-esetre megállapítandó módon.

A vármegyei törvényhatóságok komoly megfontolás tárgyává teendők, váljon az önkéntes tüzoltói intézményt nem lehetne-e bizonyos esetekben meghonosítani akként, hogy két vagy több község vagy egy körjegyzőséget képezö községek közösen alkossanak önkéntes tüzoltóságot? Ez természetszerüleg csak ott mutatkozik czélszerünek hol a községek aránylag elég közel vannak egymáshoz arra, hogy tüzveszély esetén a segély mindenkoron gyorsan érkezhessék meg.

18. §.

Mindazon községekben, melyekben sem díjazott, sem önkéntes tủzoltóság fel nem állítható a jelen rendelet közhírré tételétől számított legkésőbb egy év alatt, a község 20-40 éves férfi lakói sorából községi (köteles) tüzoltóság szervezendő és életbe léptetendő.

19. §.

Minden tüzoltó jogosult, szolgálatban pedig köteles ebbeli minőségét kitüntető, szabályrendeletileg megállapított jelvényt viselni, melyet másnak, mint tűzoltónak, viselni 10 forintig terjedhető pénzbüntetés terhe alatt tilos.

20. .

A szolgálatban levő tűzoltó közhatósági személynek tekintendő.

21. §.

A tüzvésznél magát kitüntetett tüzoltó jutalmazandó. A működésben önhibáján kívül károsult vagy szerencsétlenül járt tűzoltó a kár és munkaképtelenség mérvéhez illő módon a tehetségig segélyezendő s ily alap létesítendő. A segély az illető körülményeihez képest egyszer mindenkori kielégítés vagy állandóan húzandó évi segélyösszegböl, teljes munkaképtelenség $\mathrm{s}$ vagyonhiány esetében pedig községi ápolás és ellátásból állhat.

22. .

Oly önkéntes tűzoltó-testület mely a méltányos követelményeknek s a jelen kormányrendelet szabványainak fegyelem és szakszerü kiképzés tekintetében meg nem felel, a tűzrendészeti első fokú hatóság által feloszlatandó.

\section{FEJEZET}

A tüzvész tartamára és azutánra vonatkozó intézkedések

23.§.

A vész színhelyén az oltási technika tekintetében a tűzoltó-parancsnok intézkedik: azonban intézkedéseiért felelős.

24. §.

A vész színhelyén, akkor, ha több tüzoltóság van jelen, a müszaki vezérlet a helyi tüzoltóság parancsnokát illeti meg. Ott, hol díjazott tüzoltóság vagy önkéntes tűzoltóság nincs, a müszaki vezetést a segélyre elsőnek megérkezett szervezett tüzoltóság parancsnoka eszközli.

25. §.

A tűzoltás czéljából magántulajdonba való beavatkozás csak indokolt szükség esetében s akkor is csak a vezénylő parancsnok rendeletére történhetik. 
26. .

Ha a tüz eloltatott, a községi elöljáró, a hol pedig rendőrség volt jelen, a rendőri tisztviselő a jelen volt vezénylő parancsnok, nemkülönben a szükséges tanuk és szakértők közremüködésével azonnal köteles a tüzvész okaira nézve a legbehatóbb kutatást eszközölni, a tűzvész okát lehetőleg biztosan kinyomozni, s figyelemmel lenni, nem történt-e oly cselekmény vagy mulasztás, mely a törvénybe ütközik s kit terhel az? Végre a tüzoltó s mentő intézkedések megfeleltek-e rendeltetésüknek? Ha valaki ellen alapos gyanú támad a bünt. törv. által tiltott cselekmény vagy mulasztás miatt, a jelentés az illetékes bírósághoz azonnal beadandó.

A tüz eredetének megállapítása iránt eszközölt vizsgálatról azonnal jegyzőkönyv veendő fel, mely a vizsgálatot eszközlők által aláírandó.

Ezen jegyzőkönyv szigorúan azon minta szerint veendő fel, mely az 1870. évi aug. 24-én 3339. B. M. sz. a. kelt körrendelettel (lásd Rendeletek Tárát 361. oldalon), s 1879. évi okt. 22- én 47,281. sz. a. kelt körrendelettel (lásd a Rendeletek Tárát 588. oldalon) megállapíttatott. Ezen jegyzőkönyv további intézkedés végett rögtön a fölöttes hatóság elé terjesztendő.

\section{7. §.}

Ezen tüzvizsgálatokról felvett jegyzőkönyvek alapján az úgynevezett ártatlansági bizonyítványok csak az 1882. évi augusztus 14-én 32,706. és szeptember 17-én 49,925 számok alatt kiadott belügyministeri körrendeletek értelmében adhatók ki. (L. Rend. Tára 1123. és 1125. oldal.)

\section{FEJEZET \\ Büntetőeljárás}

28. §.

A jelen rendelet ellen vétők tekintetében azon hatóságok bíráskodnak, melyek az 1880. évi augusztus. 17-én 38,547. sz. a. kelt bel- és igazságügyministeri rendelettel megállapítvák, s ezek azon módon járnak el, miként az ott körülírva van. (1880. évi Rend. Tára 629. és következö lapjai.)

29. §.

A büntetés mérve a kihágásokról szóló törvény (1879: XL.) 141. és 142. §-aiban van meghatározva s az ezek alapján kiszabott pénzbüntetések az 1887. évi VIII. törvényczikkben megállapított czélokra fordítandók.

30. §.

Jelen rendelet, illetve az ennek alapján kiadott szabályrendeletek oly meghagyásai ellen elkövetett kihágások, melyek a kihágási törvény 141. és 142 . §-ai alá nem esnek, 2 forinttól 50 forintig terjedhető pénzbüntetéssel illettethetnek, s ezek vagy a tủzoltó alapra, vagy a tüzoltói segélyalapra, esetleg más, szabályrendeletileg megállapítandó czélokra fordíthatók.

\section{FEJEZET}

Köztörvényhatósági felügyelet

\section{1. §}

Minden köztörvényhatóság a jelen rendelet vételét követő legközelebbi közgyülésen azt tárgyalni s az iránt intézkedni köteles.

Ezen intézkedés a rendeletnek közhírré tételéből és egy - a vidéki viszonyoknak megfelelő - cselekvési programnak megállapításából áll.

$32 . \S$.

A közgyülésnek a közhírré tételre, nemkülönben a programnak megállapítására vonatkozó határozatai, legkésőbb 14 nappal a közgyủlés után, külön jelentésben a belügyministeriumnak tudomására hozandók.

\section{3. §.}

Az ekként tett intézkedések tényleges eredményéröl pedig minden törvényhatóság 1888. évi deczember 15-ig a belügyministeriumnak tüzetes jelentést adni tartozik.

34. §.

A törvényhatóság első tisztviselője (alispán, polgármester), továbbá a főszolgabírák a tűzrendészetet kiválólag gondozni, a felett felügyelni, azt folyton nyilvántartani s a mutatkozó szükség szerint, lehetőleg fejleszteni kötelesek.

$35 . \S$.

A belügyministerium fenntartja magának, hogy a tüzrendészet állapotáról és fejlődéséről a rendes hivatalos úton felül oly külön megbízottnak kiküldésével is szerzend alapos tudomást, kik a magyar országos tüzoltó-szövetség választmányának ajánlatára, vagy magának a választmánynak, vagy a tüzoltó-testületek parancsnokai sorából fognak választatni.

\section{Zárhatározat}

Jelen rendelet hatálya a Budapest fővárosra nem terjed ki.

36. .

Forrás ! Magyarországi Rendeletek Tára, XXII.évf. (1888) I. füzet. 1127-1128.p. 
49 925/1882.BM.kr.

az öngyújtogatásra csábító túlbiztosítások meggátlása.

Minthogy több törvényhatóságnak és gazdasági egyletnek részint közvetlenül hozzám, részint a földmívelés-, ipar- és kereskedelmi miniszter úrhoz intézett, s a nevezett miniszter úr által velem is közölt felterjesztésből arról értesültem, hogy országszerte általánosan azon nézet van elterjedve, miszerint az előforduló számos tüzeset onnan keletkezik, mivel a biztosítótársulatok részéröl alkalmazott úgynevezett mozgóügynökök a közönséget minden tőlük kitelhető módon magas biztosítás eszközlésére igyekszenek rávenni, minek folytán igen gyakran túlbiztosítás és ezekből eredőleg öngyújtogatások történnek; minthogy továbbá a kereskedelmi törvény 470 . §-a értelmében a biztosítási összeg a tárgyak teljes értékét meg nem haladhatja sőt, ha a túlbiztosítás bebizonyíthatólag rosszhiszemüleg történt, az egész biztosítás érvénytelen, az idézett törvény 478. §a szerint pedig a biztosított tárgy teljes megsemmisülése esetében kártérítés fejében egyedül a biztosítási összeg fizettetik ki (mely összeg azonban nem lehet nagyobb, mint a tárgy értéke a megsemmisítés idejekor), de részbeni megsemmisülés esetébe ezen kártérítésnek is csak azon arányban van helye, a melyben a biztosítási összeg a tárgyak összértékéhez áll: az úgynevezett ártatlansági bizonyítványok kiállítása tárgyában folyó év augusztus hó 14-én 32.706 sz. a. kibocsátott rendeletem kapcsán fölhívom a törvényhatóságot, hogy a vidéki közönséget a túlbiztosításnak úgy anyagi mint erkölcsi tekintetében káros következményeire figyelmeztesse, $\mathrm{s}$ erélyesen hasson oda, miképp a biztosítók a házaló ügynökök fentebb jelzett irányú törekvéseit saját érdekükben utasítsák vissza.

Kelt Budapesten, 1882. szeptember hó 17-én.

Tisza s. $k$.

Forrás ! Magyarországi Rendeletek Tára, XVI.évf. (1882) I. füzet. 1125-1483.p.

32 706/1882.BM.kr.

V.sz.melléklet

\section{tüzesetek alkalmával a tüz támadásának közvetlen okai iránt felveendö jegyzökönyvek és azok alapján kiállítandó úgynevezett „ártatlansági bizonyitványok” ügyében.}

Kétségtelen, hogy a tüzkár elleni biztosítás üdvös intézményének minél szélesebb körben való meghonosítása a biztosítás olcsóságától függ.

Minthogy pedig a biztosító intézetek és társaságok annál alacsonyabb biztosítási tételeket állapíthatnak meg, minél kevésbé vannak kitéve azon veszélynek, hogy a tüzkár elleni biztosítás egyesek részéről bünös szándékkal könnyen hozzáférhető jövedelmi forrássá tétessék: a biztosítási intézmény közérdekű voltánál fogva a közigazgatási hatóságoknak is feladatukban áll, tölük kitelhetőleg oda hatni, hogy a biztosító intézetek az öngyújtogatások folytán rájuk háramolható károktól lehetőleg megóvassanak.

Amint a törvényhatóság előtt tudva lesz, a biztosító intézetek és társaságok a kártérítési összegeket rendszerint a hatóság által a károsult részére kiállított úgynevezett - ártatlansági bizonyítványok - bemutatása után fizetik ki, azon jóhiszemü feltevésben, hogy azok az illetők részére csak a tüzvész eredete és okai iránt megejtett alapos és lelkiismeretes vizsgálat alapján szolgáltatnak ki

Tekintettel egyrészröl a fentebb előadottakra, valamint azon körülményre, hogy az öngyújtogatás következményei által nemcsak maga a biztosítási intézmény, hanem a közerkölcsiség is nagy sérelmet szenved, másrészröl pedig arra, hogy az - ártatlansági bizonyítványok - könnyelmű kiállítása a netaláni gyújtogatóknak méltó megbüntetését meghiúsíthatja: hivatkozólag az 1870. évi augusztus hó 24-én, 3.339. sz. alatt kibocsátott körrendeletemre, felhívom a törvényhatóságot, hogy a területén levő községi elöljáróságokat szigorúan utasítsa, mikép tüzeseteknél a tűz támadásának közvetlen okai (t. i. gyújtogatás, gondatlanság vagy hanyagság, villámcsapás stb.) iránt jegyzőkönyvek felvétele mellett kellő eréllyel s alapos és minél gyorsabb vizsgálatot ejtsenek meg, s csak ezen vizsgálat befejezése után és annak eredményéhez képest állítsák ki az illetők részére az ártatlansági bizonyítványokat; megjegyezvén, hogy megyékben az ily ártatlansági bizonyítványok hitelesség és ellenőrzés szempontjából minden egyes esetben az illetékes szolgabíró által is láttamozandók.

Kelt Budapesten, 1882. augusztus hó 14-én.

a minister helyett:

Prónay József s. $k$. államtitkár

Forrás ! Magyarországi Rendeletek Tára, XVI.évf. (1882) I. füzet. 1123-1124.p. 
230 000/1925.BM.kr.

a tüzrendészetről alkotott 53 888/1988.BM.r. kiegészitéséröl, módositásáról és végrehajtásáról.

A tủzrendészet jóságához és ezzel kapcsolatban az emberéletet s vagyont, tehát nemzeti értékeket veszélyeztető tűzvészek pusztításának lehető megakadályoztatásához országos érdek füződik. Kiváltképen fontos ez - nemzetgazdasági szempontból is - hazánk jelenlegi súlyos helyzetében.

Annál sajnálatosabb, hogy az országban mind sürübben előforduló tűzesetek körülményeit részletesen megvizsgálva, azt kell megállapítanom, hogy tüzrendészetünk nagy mértékben hiányos, az a közöny pedig, amellyel egyes vidékeken közigazgatásunknak ezt az egyik legfontosabb ágát — föként a tüzoltóságok szervezését és felszerelését — kezelik, szinte már, a lelkiismeretlenséggel határos.

Megállapításom szerint ennek oka nem annyira az elvi rendelkezések hiányában, hanem inkább abban rejlik, hogy a fennálló szabályok - elsősorban pedig a tűzrendészetről szóló 53.888/1888. B. M. szám alatt kiadott alapvető rendelet ${ }^{2}$ - ren- $^{-}$ delkezései teljes egészükben nincsenek mindenütt végrehajtva.

Ezért legfőbb idejét és szükségét látom annak, hogy addig is, amíg országunk helyzete a tüzrendészetnek, és fökép a tüzoltóság intézményének szélesebb keretek között való újjáépítését megengedi, az imént idézett s az alábbi rendelkezésekkel a szükséghez képest módosított, illetőleg kiegészített 53.888/1888. B. M. számú rendelet tökéletes és lelkiismeretes végrehajtását minden körülmények között biztosítsam.

E célból - a minisztertanács felhatalmazása alapján - a következöket rendelem :

I.

Tüzrendészeti és építési szabályrendeletek.

1. §. Mindazok a községek, r. t. városok és törvényhatóságok, amelyek az idézett rendelet 2 . §-ában elöírt tüzrendészeti szabályrendeletet, továbbá azok a r. t. városok és törvényhatóságok, amelyek a rendelet 5. §-ában említett építési szabályrendeletet eddig meg nem alkották, ezt a mulasztásukat legkésőbb e rendelet életbelépésétől számított 6 hónap alatt pótolni kötelesek.

A községi elöljáróságok tagjai, a r. t. városok polgármesterei és a törvényhatóságok első tisztviselői személyes, fegyelmi felelősség terhe alatt kötelesek a szabályrendelet alkotását előkészítő intézkedéseket kellő időben megtenni.

2. §. Ott, ahol tüzrendészeti, vagy építkezési szabályrendelet van, ezeket az újabb tüzvédelmi szempontok figyelembevételével az 1. §-ban megjelölt határidőn belül át kell vizsgálni és a szükséghez képest módosítani kell.

E tekintetben a Magyar Országos Tüzoltó Szövetség kívánatra, útbaigazító szakvélemyényt ad.

II.

Tüzoltószerek.

3. §. Azok a községek, összeépített puszták, tanyák stb., amelyekben 50 lakóháznál nincs több, a következő tüzoltószereket kötelesek beszerezni és készenlétben tartani :

legalább 1 szívó-nyomó fecskendőt (két $80 \mathrm{~mm}$.-es hengerüt), $60 \mathrm{~m}$. nyomótömlőt (orsz. egységes csavarral), $8 \mathrm{~m}$. szívótömlőt, 1 csáklyát, 2 vasvillát, 1 petróleumos fáklyát, avagy lámpást, 1 fejszét, 2 vedret és $20 \mathrm{~m}^{2}$ nagyságú takaróponyvát. Minden, legalább 50-300 lakóházat számláló község köteles az alább felsorolt tűzoltószereket beszerezni, ezeknek szükségszerü kiegészítéséröl és jó helyen, állandóan jókarban tartásáról gondoskodni :

1. legalább két $100 \mathrm{~mm}$-es hengerrel bíró szívó-nyomó fecskendőt, amely percenkinti 100 löketnél legalább 160 liter vízszállító képességgel és $26 \mathrm{~m}$. sugártávval, könnyen és gyorsan hozzáférhető szelepszerkezettel, országos egységes nyomóoldali szabványos csavarzattal, legalább $100 \mathrm{~m}$. szállító kendertömlővel (15-20 m.-es darabokban) és 4, egyenkint $2 \mathrm{~m}$. hosszú szívótömlővel és 2 sugárcsővel és 1 sugárosztóval, olajozóval, fakalapáccsal és a szükséges csavarkulcsokkal van felszerelve ; továbbá 1, legalább 5 hektoliter ürtartalmú vízhordókocsit 1 hektoliter ürtartalmú káddal, 2, egyenkint 5 -6 m. hosszú támasztólétrát, 2 csáklyát, 2 fejszét, 2 vasvillát, 2 kalapácsot, 2 petróleumfáklyát vagy lámpást, 6 vedret és 2, egyenkint $20 \mathrm{~m}^{2}$ nagyságú takaróponyvát.

Minden 300-700 házból álló község a fentieken kívül még 1 (tehát összesen 2) felszerelt szívó-nyomó fecskendőt tartozékaival és még egy, $20 \mathrm{~m}^{2}$ nagyságú takaróponyvát ;

a 700-1000 házból álló község pedig még 2 (tehát összesen 3) teljesen felszerelt szívó-nyomó fecskendőt és még egy harmadik takaróponyvát köteles beszerezni. Eltérésének az esetben van helye, ha valamely község megfelelő nyomású vízvezetékkel hír, vagy azt a helyi körülmények indokolttá teszik.

Nagyobb községek és városok az épületek arányában szükségesnek mutatkozó, megfelelő mennyiségű tüzoltószert kötelesek tartani.

A tủzoltószerek szükséges mennyiségét és minőségét - kétség esetén - a belügyminiszter állapítja meg, aki az egyes községeket és városokat a szükséges költségnek a háztartási költségvetésbe való felvételére felhívhat] a, s a felhívás eredménytelensége esetén a megfelelő tétel felvételét elrendelheti.

A gyárak, malmok s nagyobb ipartelepek tulajdonosait az illetékes I. fokú tüzrendészeti hatóság a szükséghez képest megfelelő tüzoltószerek beszerzésére és tartására kötelezheti, s az üzemek folytatását e kikötés teljesítésétől teheti függővé. Nagyobb uradalmak a szükséges tüzoltószerek beszerzésére és tartására szintén kötelezhetők.

A tüzoltószerek beszerzésénél az erre vonatkozólag kiadott külön miniszteri rendeleteket (82.502/1888., 6.840/1889., 83.860. 1902. B. M. sz.), valamint a Magyar Országos Túzoltó Szövetség által közölt egységes elöírásokat kell figyelembe venni.

Azokban a községekben, ahol a már meglevő és egyébként még használható fecskendők nem felelnek meg az egységes elöírásnak, e tüzoltófecskendőket megfelelően át kell alakítani.

A községek és városok a beszerzéseknél a tűzrendészeti felügyelő, illetőleg tűzoltóparancsnok véleményét minden egyes esetben kérjék ki. 
A tűzoltószereket e rendelet hatályba lépésétől számított egy év alatt kell beszerezni. Halasztásnak csak különösen indokolt esetekben lehet helye.

4. §. Az oltáshoz szükséges vízmennyiség biztosításáról azok a községek és városok, ahol e tekintetben hiány mutatkozik, megfelelő kutak, medencék stb. létesítésével a legsürgősebben gondoskodni kötelesek.

III.

Tüzoltói készenlét, tüzjelzés.

5. §. A legalább 300 lakóházból álló minden község köteles akár a helybeli önkéntes tüzoltótestület, akár a köteles tüzoltóság útján, akár pedig egyébként a nappal és az éjjel egész szakára kiterjedő és egész éven át tartó tűzoltókészenlétet rendszeresíteni. A készenlét legalább két tüzoltóból álljon, akik nappalonkint, illetőleg éjjelenkint felváltva teljesítik az őrségi szolgálatot. A tüzőrség, helyesen készenlét feladata : tüz esetén a riasztás, a tüzoltószerek készenlétbe helyezése, és a legelső tüzvédelmi és mentő intézkedések megtételéről való gondoskodás. Egyébként a tüzoltói készenlét feladata még - az elöljáróság ellenőrzése alatt - a tüzoltószerek tisztántartása és örzése is.

Kisebb községekben készenléti szolgálatot csak éjjel kell tartani ; ezt az éjjeli ör látja el. A tűzoltószerek tisztántartásáról és őrzéséről pedig a községi elöljáróság külön megbízott útján gondoskodik.

Városokban a készenléti és az azzal kapcsolatos egyéb szolgálatot a hivatásos tüzoltóság látja el.

6. §. A tüzjelzés gyorsasága megkívánja, hogy azokban a nagyközségekben és városokban, ahol telefon van, a tüzoltólaktanya, illetőleg az őrség helye is telefonállomással legyen ellátva.

Az illető községek és városok kötelesek tehát háztartási költségvetésük terhére a megfelelő telefonállomás berendezéséröl gondoskodni.

7. §. Mindazok a magánegyének, vállalatok vagy intézetek, amelyeknek a helyi telefonhálózatba bekapcsolt telefonállomásuk van, a m. kir. kereskedelemügyi miniszter úr által kiadott szabályzat értelmében is kötelesek azt tüzjelzésre, valamint baleset bejelentésre mindenkor haladék nélkül rendelkezésre bocsátani.

IV.

A tüzoltóság megszervezése.

8. §. A vármegyék első tisztviselőinek szigorú kötelességévé teszem, hogy nemcsak alárendelt hatóságaik útján, hanem személyes közremüködésükkel is gondoskodjanak arról, hogy a hatóságok területén levő mindazon községekben és r. t. városokban, ahol netán az 53.888/1888. B. M. számú rendeletben, megállapított tüzoltói intézmények egyike sem áll még fenn, azok valamelyike, és pedig r. t. városokban a hivatásos tüzoltóság legkésőbb 1925. év végéig feltétlenül felállíttassák.

9. §. Községekben - a hazafias társadalom bevonásával - elsősorban önkéntes tűzoltóegyletek létesítését kell kezdeményezni ; ezek szervezése tekintetében a Magyar Országos Tủzoltó Szövetség kormányhatóságilag jóváhagyott szervezési szabályzatának rendelkezései irányadók.

Önkéntes tüzoltó-egylet tagjaiul csak feddhetlen elöéletü és nemzeti szempontból is teljesen megbízható, 20-ik életévüket betöltött magyar állampolgárok vehetők fel.

A már fennálló községi önkéntes tüzoltó-egyletek kifejlesztésére is nagy gondot kell fordítani, és azokat a legteljesebb hatósági támogatásban kell részesíteni.

A községi önkéntes tüzoltó-egyleteket pedig az egyéb tüzoltótestületekkel együtt vármegyei szövetségekké kell tömöríteni.

10. §. Az önkéntes tủzoltó-egyletek feladatuk teljesítése tekintetében a községi elöljáróság, illetőleg városi tanács felügyelete alatt állanak, amelyeknek egy tagja (városokban a tanácsnak az általa erre kijelölt egyik tagja, községekben pedig a községi fö-, illetőleg körjegyző) az illető egylet vagy testület választmányában illetőleg parancsnokságában hivatalból foglal helyet.

Az alispánok, illetőleg Budapest székesfőváros polgármestere pedig hivatalból tagjai a vármegyei tüzoltó szövetségek, illetőleg a fơvárosi tüzoltó szövetség választmányának. Az önkéntes tüzoltótestületek parancsnokait - a budapesti önkéntes tüzoltótestület kivételével - tisztségükben az illetékes I. fokú tủzrendészeti hatóság véleményének meghallgatása után a törvényhatóság első tisztviselője erősíti meg.

11. §. A „köteles tűzoltóságot" mindazokban a községekben meg kell alakítani, ahol vagy nincs, illetőleg nem alakítható önkéntes tűzoltó-egylet, vagy a meglevő önkéntes testület akár létszám, akár kiképzés tekintetében nem felel meg a tüzvédelmi igényeknek, végül ahol egyéb körülmények (helyi építkezési viszonyok stb.) az önkéntes testület mellett a „köteles tüzoltóság” felállítását is indokolják. A „köteles tüzoltóság" alakítása oly mérvben történjék, hogy átlagban a község minden 50 lakosára egy tűzoltó essék ; egy-egy község ily tűzoltósága azonban legalább 15 főből álljon.

Mindazokban a községekben, ahol önkéntes tüzoltó-egylet van, annak parancsnoka egyszersmind a községi „,köteles tüzoltóságnak, mint az önkéntes testület kiegészítő részének is parancsnoka. Ahol pedig önkéntes testület nincs, ott a „köteles tüzoltóság" parancsnoki teendőit a tüzoltóságnak feddhetlen előélet és nemzeti megbízhatóság szempontjából is alkalmas az a tagja köteles ellátni, akit erre a község képviselötestülete kijelöl, illetőleg megbíz. A kijelölt parancsnokot vagy parancsnokokat tisztségükben az illetékes járási föszolgabíró véleményének meghallgatása után a vármegye alispánja erősíti meg.

A köteles tűzoltói szolgálat alól csak a szolgálat ellátásában különleges hivatali elfoglaltságuk miatt tartósan gátolt közszolgálati alkalmazottak, és a hitelesen igazolt betegségük folytán egészségi szempontból szolgálatra alkalmatlan községi lakosok mentesíthetők.

A mentesítés kérdésében az illetékes járási főszolgabíró határoz, akinek határozata ellen - az e rendelet VII. fejezetében felsorolt fellebbviteli hatósághoz - fokozatos fellebbvitelnek van helye. A köteles tüzoltóság szolgálati jelvényéről és felszereléséről - teherbíró képessége arányában - a község köteles gondoskodni, úgyszintén a szolgálattal esetleg felmerülő költségek megtérítéséről is. 
A község (város) az önkéntes és köteles tüzoltóság tagjait baleset ellen biztosítani köteles. A biztosítás a Magyar Országos Tüzoltó Szövetség segélypénztára útján történik.

12. §. Az önkéntes, vállalati és köteles tüzoltóságok szolgálata tekintetében az egyes helyhatósági szabályrendeleteken kívül a Magyar Országos Tüzoltó Szövetség egységes szolgálati szabályzata irányadó.

13. §. Rendezett tanácsú és törvényhatósági joggal felruházott városokban, ott, ahol még eddig rendszeresítve nincs, rendszeres (hivatásos) tüzoltóságot kell létesíteni, és ennek díjazásáról és felszereléséről az illető város a háztartási költségvetésben köteles - megfelelő fedezet biztosítása mellett - gondoskodni. E mellett azonban a városokban az önkéntes tüzoltóegyletek alakulását is elő kell mozdítani s a meglevő ily egyleteket hatósági támogatásban kell részesíteni. Azokban a városokban, ahol önkéntes mentőegyesület nincs, és annak alakítása akadályokba ütközik, a mentőszolgálatot is a hivatásos tüzoltóság keretében kell megszervezni.

14. §. Hivatásos tűzoltó és tiszt is csak feddhetlen előéletű és nemzeti szempontból teljesen megbízható magyar állampolgár lehet ; 20 éven aluli kiskorú felvétele még szülöi, illetőleg gyámi hozzájárulás esetén sem engedhető meg. Hivatásos tűzoltótiszti vagy parancsnoki állás betöltéséhez legalább a középiskolai (vagy azzal egyenrangú egyéb iskolai) végzettségen kívül az országos tủzoltótiszti tanfolyam elvégzésének és a tüzoltótiszti képesítő vizsga sikeres letételének igazolása is szükséges. Törvényhatósági joggal felruházott városok rendszeres (hivatásos) tüzoltóságának föparancsnoka csak az lehet, akinek a tüzoltótisztekre és parancsnokokra imént elöírt feltételeken kívül főiskolai (és pedig : müegyetemi, erdészeti, bányászati, jogi vagy államtudományi, illetőleg közgazdasági egyetemi) végzettsége is van. A müegyetemi, erdészeti vagy bányászati főiskolai végzettséggel rendelkezőket, egyenlő feltételek esetén pedig a világháborúban arcvonal-szolgálatot teljesített egyéneket az alkalmaztatásnál rendszerint előnyben kell részesíteni.

Tüzoltóaltiszt pedig csak az lehet, akit a felettes parancsnoksága a hivatásos testület keretében megszerzett elméleti és gyakorlati képzettsége alapján az altiszti rangfokozat elnyerésére képesít.

A már alkalmazásban lévő tűzoltótisztek és altisztek a hiányzó illetékes járási főszolgabíró véleményének meghallgatása után a vármegye alispánja erösíti meg.

A köteles tủzoltói szolgálat alól csak a szolgálat ellátásában különleges hivatali elfoglaltságuk miatt tartósan gátolt közszolgálati alkalmazottak és a hitelesen igazolt betegségük folytán egészségi szempontból szolgálatra alkalmatlan községi lakosok mentesíthetők.

A mentesítés kérdésében az illetékes járási föszolgabíró határoz, akinek határozata ellen - az e rendelet VII. fejezetében felsorolt fellebbviteli hatósághoz - fokozatos fellebbvitelnek van helye.

A köteles tüzoltóság szolgálati jelvényéről és felszereléséről - teherbíró képessége arányában - a község köteles gondoskodni, úgyszintén a szolgálattal esetleg felmerülő költségek megtérítéséröl is.

A község (város) az önkéntes és köteles tüzoltóság tagjait baleset ellen biztosítani köteles. A biztosítás a Magyar Országos Tüzoltó Szövetség segélypénztára útján történik.

Az önkéntes, vállalati és köteles tüzoltóságok szolgálata tekintetében az egyes helyhatósági szabályrendeleteken kívül a Magyar Országos Tüzoltó Szövetség egységes szolgálati szabályzata irányadó. Rendezett tanácsú és törvényhatósági joggal felruházott városokban, ott, ahol még eddig rendszeresítve nincs, rendszeres (hivatásos) tủzoltóságot kell létesíteni és ennek díjazásáról és felszereléséről az illető város a háztartási költségvetésében köteles - megfelelö fedezet biztosítása mellett gondoskodni.

E mellett azonban a városokban az önkéntes tüzoltóegyletek alakulását is elő kell mozdítani s a meglevő ily egyleteket hatósági támogatásban kell részesíteni.

Azokban a városokban, ahol önkéntes mentőegyesület nincs és annak alakítása akadályokba ütközik, a mentőszolgálatot is a hivatásos tüzoltóság keretében kell megszervezni.

17.§. Hivatásos tủzoltó és tiszt is csak feddhetetlen előéletü és nemzeti szempontból teljesen megbízható magyar állampolgár lehet; 20 éven aluli kiskorú felvétele még szülői, illetőleg gyámi hozzájárulás esetén sem engedhető meg. Hivatásos tűzoltótiszt vagy parancsnoki állás betöltéséhez legalább a középiskolai (vagy azzal egyenrangú egyéb iskolai) végzettségen kívül az országos tủzoltótiszti képesítő vizsga sikeres letételének igazolása is szükséges. Törvényhatósági joggal felruházott városok rendszeres (hivatásos tűzoltóságának föparancsnoka csak az lehet, akinek a tüzoltótisztekre és parancsnokokra imént elöírt feltételeken kívül föiskolai (és pedig: mủegyetemi, erdészeti, bányászati, jogi vagy államtudományi, illetőleg közgazdasági egyetemi) végzettsége is van. A műegyetemi, erdészeti vagy bányászati főiskolai végzettséggel rendelkezőket, egyenlő feltételek esetén pedig a világháborúban arcvonal-szolgálatot teljesített egyéneket az alkalmaztatásnál rendszerint előnyben kell részesíteni.

Tüzoltóaltiszt pedig csak az lehet, akit a felettes parancsnoksága a hivatásos testület keretében megszerzett elméleti és gyakorlati képzettsége alapján az altiszti rangfokozat elnyerésére képesít.

A már alkalmazásban lévő tủzoltótisztek és altisztek a hiányzó képzettség utólagos megszerzésére rendszerint nem kötelezhetők. A belügyminiszter méltánylást érdemlö esetekben az iskolai képzettség igazolása alól felmentést adhat.

Egyébként a rendszeres (hivatásos) tüzoltóság kötelékébe tartozók személyi, szolgálati és fegyelmi viszonyainak szabályozása az illető város önkormányzati hatáskörébe tartozik.

Ugyancsak a város képviselőtestülete, illetőleg törvényhatósági bizottsága állapítja meg a tüzoltósága létszámát is. Azonban minden testületnek legalább 8 szakképzett tagjának kell lennie.

A belügyminiszter kivételes esetben, t.i. ha a megállapított létszámot túl alacsonynak tartja, a létszámnak a szükséglethez és a helyi viszonyokhoz mért felemelését rendelheti el.

A rendszeres tüzoltóságok tagjai a tüzoltói, illetőleg mentőhivatásukkal össze nem egyeztethető más szolgálatokra fel nem használhatók.

15.§. Az önkéntes, vállalati és köteles tüzoltóságok tagjainak és a tüzrendészeti felügyelőknek egyéni felszerelése (egyenruházata stb.) és rangjelzése tekintetében a Magyar Országos Tüzoltó Szövetségnek 1909. október 16-án kiadott szabályzata kötelező. A törvényhatósági joggal felruházott, valamint a rendezett tanácsú városok rendszeres (hivatásos) tűzoltóságainak tagjai csakis a város közönség által megállapított egyenruhát viselhetik.

Tüzoltói egyenruhát vagy jelvényt más, mint működő (tényleges állományú) tüzoltó nem viselhet Aki e rendelkezéseket megszegi, vagy kijátssza, az 1879:XL. T.-cikk 44.§-a alapján büntetendö kihágást követ el. 
16.§. A szolgálatban álló tűzoltó a büntető törvények alkalmazása szempontjából ugyanolyan tekintet alá esik, mint az 1914:XL. t.-cikk 5.§-ában felsorolt azok az alkalmazottak, akik a közönség személyének vagy vagyonának védelmére rendelvék.

V.

Tüzoltótanfolyamok.

17.§. A belügyminiszter a Magyar Országos Tűzoltó Szövetség útján időnkint a szükség mérvéhez képest - tűzoltótiszti képesítő vizsgával egybekötött - országos tüzoltótiszti tanfolyamot nyit.

Azok a törvényhatósági joggal felruházott városok, amelyek egyszersmind vármegyei székhelyek is, az illető vármegyei tűzoltószövetség közreműködése és esetleges anyagi hozzájárulása mellett, évenkint tűzoltó-tanfolyamot kötelesek létesíteni.

A tủzoltótiszti és tủzoltói tanfolyamok szabályzatát külön belügyminiszteri rendelet fogja megállapítani.

18.§. A rendszeres (hivatásos) tüzoltótestületek legénységét a szakszerü, elméleti és gyakorlati kiképzésen kívül a testület keretében általános ismeretterjesztő, kiváltképpen a nemzeti érzést és a vallásosságot fejlesztő rendszeres előadásokban is kell részesíteni.

Fölötte kívánatos, hogy az önkéntes és „köteles” tűzoltótestületek hasonlókép járjanakel.

IV.

Tüzvész tartamára vonatkozó rendelkezések.

19.§. Tüzvész esetén az önkéntes és vállalati (gyári) tüzoltóságok a helybeli hivatásos tüzoltóságnak a legnagyobb segítségére lenni és - a vállalat (gyár) helyén szükséges készenlét visszahagyása mellett - felszerelésükkel is rendelkezésre állani kötelesek.

Tüzvész idején a község lakosait fogatszolgáltatás kötelezettsége terheli.

Tüzvész esetén a szomszédos községek, illetőleg azok tűzoltóságai a tűz elleni védekezésben résztvenni, illetőleg a helybeli tüzoltóságnak a legmesszebbmenő támogatást nyújtani kötelesek.

Ennek, valamint a soros fogatszolgáltatás teljesítésének módozatait a tüzrendészeti szabályrendeletekben kell megállapítani.

VII.

Tüzrendészeti hatóságok.

20. §. Kétségek eloszlatása céljából megállapítom, hogy tűzrendészeti ügyekben az alábbi hatóságok jogosultak eljárni.

Elsőfokon :

kis- és nagyközségekben : a járási főszolgabíró,

r. t. városokban : a polgármester,

thjf. városokban : a tanács által kijelölt tisztviselö,

Budapesten : a kerületi elöljáró.

Másodfokon :

kis- és nagyközségekben, valamint r. t. városokban : az

alispán,

thjf. városokban és Budapesten : a tanács.

Harmadfokon :

a belügyminiszter.

VIII.

Büntető rendelkezések.

21. §. Az 53.888/1888. B. M. számú rendelet 28-30. §-ai helyébe a következö büntető rendelkezések lépnek:

Aki az 53.888/1888. B. M. számú rendeletnek, valamint e rendeletnek rendőri rendelkezéseit vagy tilalmait megszegi vagy kijátsza, avagy azok kijátszásában bármely módon közremüködik, amennyiben cselekménye súlyosabb büntető rendezés alá nem esik, kihágást követ el, és ha a cselekmény, illetve mulasztás nem az 1879 : XL. t.-c. alapján büntetendő, e rendelet alapján 15 napig terjedhető elzárással és $1,000.000$ koronáig terjedhető pénzbüntetéssel büntetendő.

E kihágás miatt az eljárás a közigazgatási hatóságok, mint rendőri büntetőbíróságok, a m. kir. államrendőrség müködése területén pedig az államrendörség hatáskörébe tartozik.

IX.

Felügyeleti rendelkezések.

22. §. A tüzrendészet nagyobbmérvű ferjesztése érdekében elengedhetetlenül szükséges, hogy — jövőre — rendszeres, közszolgálati illetménnyel ellátott vármegyei tűzrendészeti felügyelői állások szerveztessenek.

Addig is, amíg ezt a szervezést a törvényhatóságok pénzügyi és gazdasági helyzete lehetővé fogja tenni, a tűzrendészeti felügyelet hatályosabbá tétele céljából a következőket rendelem: 
Mindazokban a vármegyékben, ahol tiszteletdíjjal ellátott vármegyei tűzrendészeti felügyelök már működnek, azok, valamint a járási tiszteletbeli felügyelők alkalmaztatását, illetőleg müködését továbbra is fenn kell tartani. Ezek szolgálati és fegyelmi tekintetben a vármegyei tisztviselőkre hatályos jogszabályok alá esnek.

Azokban a vármegyékben pedig, ahol tiszteletdíjas vármegyei tűzrendészeti felügyelök még nem működnek, a vármegyei tüzrendészeti felügyelő feladatkörének ellátásával a vármegye egyik főiskolai végzettségű tisztviselőjét kell megbízni. Az ekként megbízott tisztviselőnek módot kell nyújtani arra, hogy valamely törvényhatósági joggal felruházott város hivatásos tủzoltóságánál a szükséges gyakorlati ismereteket teljesen elsajátíthassa, ezt követően a Magyar Országos Tủzoltó Szövetség keretében nyitandó tủzoltótiszti tanfolyamot elvégezhesse, és a tanfolyamot befejező tủzoltótiszti képesítést is megszerezhesse.

A már alkalmazott tiszteletdíjas vármegyei tüzrendészeti felügyelök és a tüzrendészeti felügyelői tennivalókkal újabban megbízandó vármegyei tisztviselők feladatköre a következő : A vármegyei tüzrendészeti felügyelő tűzrendészeti ügyekben a vármegye szakközege. Feladata főképpen : az egyes községekben - és az alispán utasítására rendezett tanácsú városokban is a tủzoltóságok szervezését előmozdítani, az egyes tủzoltóságokat, azok felszerelését, a tủzoltószerek jókarban létét és megfelelő elhelyezését, továbbá a tüzőrségi készenlétet állandóan szakszerüen felülvizsgálni és ellenőrizni. E célból köteles félévenkint legalább egyszer a vármegye minden községébe kiszállani és az észlelt hiányok pótlására a községi elöljáróságokat felhívni, s erről esetenkint az illetékes járási főszolgabíróknak is jelentést tenni. Kiszállásain a felügyelő községi előfogatot vehet igénybe. A tủzrendészeti felügyelő, aki müködéséről rendszeres müködési naplót köteles vezetni, helyszíni kiszállásain szerzett tapasztalatai alapján a községek tűzrendészeti állapotáról negyedévenkint a vármegye első tisztviselőjének jelentést tesz, aki a hozzá beérkezett jelentéseket saját véleménye kíséretében ugyancsak negyedévenkint a belügyminiszterhez felterjeszti.

A megyei tüzrendészeti felügyelő köteles a vármegyei I-ső és Il-od fokú tüzrendészeti hatóságoknak mindennemü tüzrendészeti (építési és telepengedélyezési) ügyben szakvéleményt adni, és egyes községeket tüzrendészeti kérdésekben szakszerü útbaigazítással ellátni. A tüzrendészeti hatóságoknak fontosabb tűzrendészeti ügyekben a megyei tüzrendészeti felügyelöt minden esetben szakvélemény adására kell felhívniok. Köteles továbbá a vármegyei tủzrendészeti felügyelő a belügyminiszternek egyes helyszíni szemlék foganatosítására vonatkozó utasításait teljesíteni, és a belügyminiszter kiküldötteinek ellenőrző szemléin a kiküldötteknek szakszerü kérdésekben rendelkezésére állani. A törvényhatósági joggal felruházott városok rendszeres (hivatásos) tüzoltóságának föparancsnokai a város területén a vármegyei tüzrendészeti felügyelő feladatát is ellátják.

23. §. A vármegyei tủzrendészeti felügyelő müködése a hatósági ellenőrzés fokozása érdekében történvén, a megyei I. és II. fokú tüzrendészeti hatóságok vezetőit nem menti fel az 53.888. 1888. B. M. számú rendeletben és egyéb törvényes rendelkezésekben előírt ellenőrző kötelességük lelkiismeretes teljesítése alól.

24. §. A belügyminisztert megillető tüzrendészeti föfelügyeleti jog alapján központi kiküldötteim útján a rendszeres ellenőrző szemléket az ország egész területén ezután is meg fogom tartani.

$\mathrm{X}$.

Záró rendelkezések.

25. §. Az 53.888/1888. B. M. számú rendeletnek e rendelettel nem módosított, vagy hatályon kívül nem helyezett rendelkezései érvényükben változatlanul fennmaradnak.

26. §. Ezt a rendeletet - az egyes törvényhatóságok egyetemét nem érintő rendelkezései tekintetében szükséges intézkedések megtétele végett — a legközelebbi törvényhatósági bizottsági gyülésen tárgyalás alá kell venni.

27. §. Az előző szakasz értelmében, valamint a rendelet végrehajtása során egyébként tett rendelkezésekről és intézkedésekről a törvényhatóságok első tisztviselői 1925. évi december hó 31-ig és a tett intézkedések eredményéről legkésőbb 1926. évi június hó l-ig a belügyminiszterhez részletes és kimerítő jelentést kötelesek felterjeszteni.

28. §. Ez a rendelet és az ezzel módosított 53.888/1888. B. M. számú rendelet pontos és lelkiismeretes végrehajtásáért a törvényhatóságok első tisztviselöit saját személyükben fegyelmileg is felelőssé teszem, és meghagyom, hogy amennyiben a törvényhatóságok első tisztviselői az alárendelt hatóságoknál a végrehajtás tekintetében bármely mulasztást észlelnének, a megtorló eljárást a mulasztó hatósági személyekkel szemben haladék nélkül tegyék folyamatba, és minden ilyen esetről hozzám tegyenek jelentést.

Ez a rendelet, amelynek hatálya - amennyiben egyéb törvényes rendelkezések másként nem rendelkeznek - Budapest székesfővárosra is kiterjed, kihirdetésétől számított 8-ik napon lép életbe.

Budapesten, 1925. évi május hó 4-én.

Dr. Rakovszky Iván s. $k$.

m. kir. belügyminiszter.

Forrás ! Magyarországi Rendeletek Tára, XXXIX.évf. (1925) I. füzet. 249-258.p. 
1936/X.tc.

a tüzrendészet fejlesztéséröl.

1. § (1) A törvényhatósági jogú és a megyei városok hivatásos tủzoltóságot kötelesek fenntartani, amelynek élén törvényhatósági jogú városban a tüzoltófőparancsnok, megyei városban a tüzoltóparancsnok áll. A fóparancsnokot, illetőleg a parancsnokot és a hivatásos tüzoltóság tisztikarának tagjait a föispán, Budapest székesfővárosban a tüzoltófőparancsnokot a főpolgármester a hivatásos tüzoltóság tisztikarának többi tagjait a polgármester nevezi ki. A kinevezéseknél az országos tűzrendészeti felügyelőt (5. § (1) bek.) meg kell hallgatni.

(2) Nagy- és kisközségekben a tüzoltóság szervezetét és a tüzoltói szolgálat ellátását a belügyminiszter a 10. § alapján kiadott rendeletben szabályozza.

(3) A büntetőtörvények alkalmazása szempontjából a szolgálatban levő tüzoltót hatósági közegnek kell tekinteni.

2. § (1) A belügyminiszter törvényhatósági jogú, úgyszintén megyei városokat, valamint nagy- és kisközségeket teherbíróképességük figyelembevételével - tűzoltói szervezetük és berendezésük kiegészítésére kötelezhet.

(2) A törvényhatóság első tisztviselője nagy ipari és mezőgazdasági üzemeket, ha megfelelő tűzoltói berendezésük és tűzoltóságuk nincs - amennyiben a helyi viszonyok ezt indokolttá teszik - a kerületi kir. iparfelügyelö, illetőleg a vármegyei gazdasági felügyelö meghallgatásával külön tüzoltói berendezés és külön tüzoltóság fenntartására kötelezhet. Az ilyen ügyekben másodfokon a belügyminiszter az ipari üzemek tekintetében az iparügyi, a mezőgazdasági üzemek tekintetében a földmívelésügyi miniszterrel egyetértően határoz.

3. § (1) A tüzvédelmi szervezetek megállapításánál és az ilyen berendezések létesítésénél a légitámadás ellen irányuló védelem követelményeire figyelemmel kell lenni.

(2) Légitámadás veszélye esetében a veszélyeztetett város, illetőleg község tüzrendészeti szervezete - a veszély tartama alatt - a légitámadás elhárítását irányító katonai parancsnok vezetése alatt áll.

4. § (1) Tüzrendészeti ügyekben - amennyiben ez a törvény vagy ennek alapján kiadott rendelet eltérően nem rendelkezik a következő hatóságok járnak el:

elsőfokon nagy- és kisközségekben a főszolgabíró, megyei városokban a polgármester, törvényhatósági jogú városokban a polgármester által kijelölt tisztviselö, Budapesten a kerületi elöljáró;

másodfokon a törvényhatóság első tisztviselöje;

harmadfokon a belügyminiszter.

(2) Azt, hogy az ipartelepekre és a közlekedési vállalatokra vonatkozóan tűzrendészeti ügyekben mely hatóságok, illetőleg szervek járnak el, a belügyminiszter, az iparügyi, valamint a kereskedelem- és közlekedésügyi miniszterrel egyetértően rendeletben állapítja meg.

5. § (1) A belügyminiszter a tüzrendészet felett a főfelügyeletet az országos tüzrendészeti felügyelő közremüködésével gyakorolja.

(2) Az ország területét tűzrendészeti kerületekre kell felosztani; egy-egy kerület élén a kerületi tüzrendészeti felügyelő áll.

(3) A vármegye tüzrendészeti felügyeleti szerve a vármegyei, a járásé a járási tüzrendészeti felügyelö. Törvényhatósági jogú, illetőleg megyei városban a tủzrendészeti felügyeletét a hivatásos tüzoltóság föparancsnoka, illetőleg parancsnoka látja el.

(4) Az országos tüzrendészeti felügyelőt és a kerületi tüzrendészeti felügyelőket a belügyminiszter, a vármegyei és járási tüzrendészeti felügyelőket a föispán nevezi ki. A kerületi, a vármegyei és járási tüzrendészeti felügyelők kinevezésénél az országos tüzrendészeti felügyelöt meg kell hallgatni. Vármegyei és járási tüzrendészeti felügyelői tisztségre - e törvény hatálybalépése után - csak vármegyei vagy városi tisztviselőt lehet kinevezni, aki ezt a megbízást elfogadni köteles. Az országos vagy a kerületi tüzrendészeti felügyelői tisztségre kinevezett vármegyei vagy városi tisztviselő szintén köteles ezt a megbízást elfogadni.

(5) Az országos tűzrendészeti felügyelő megbizatása tíz évi, a kerületi tűzrendészeti felügyelők megbizatása öt évi időtartamra, a vármegyei és a járási tüzrendészeti felügyelők megbizatása pedig visszavonásig terjedő időre szól. Ha azonban a vármegyei vagy járási tüzrendészeti felügyelőnek vármegyei tisztviselői tényleges szolgálata bármely okból megszünik, ezzel egyidejüleg tüzrendészeti felügyelői megbizatása is véget ér.

(6) A tűzrendészeti felügyelők feladatkörük ellátásáért költségátalányt kapnak. A költségátalány nagyságát a 9. §-ban említett bevételek terhére a belügyminiszter a pénzügyminiszterrel egyetértően állapítja meg.

6. § Vármegyékben a vármegyei tűzrendészeti felügyelö, törvényhatósági jogú városokban - Budapest székesfőváros kivételével - a tüzoltóföparancsnok tagja a törvényhatósági bizottságnak, megyei városokban pedig a tủzoltóparancsnok tagja a képviselőtestületnek. Budapest székesföváros törvényhatósági bizottságának közgyülésében a tüzoltóföparancsnok jogállása ugyanaz, mint amelyet a fennálló jogszabályok (1934:XII. törvénycikk 2. §-a (2) bek.) a szakszerüség képviselőire nézve megállapítanak.

7. § A vármegyei és a törvényhatósági jogú városi (5. § (3) bek.) tüzrendészeti felügyelőnek - müködése területén - a közigazgatási hatóság határozata ellen, annak tüzrendészeti vonatkozásaiban fellebbezési joga van. A vármegyei és a törvényhatósági jogú városi (5. § (3) bek.) tüzrendészeti felügyelő azonban nem fellebbezheti meg a törvényhatóság első tisztviselője, a törvényhatósági bizottság, a kisgyülés és a közigazgatási bizottság határozatát; e hatóságok határozata ellen, annak tüzrendészeti vonatkozásaiban a fellebbezés joga a kerületi tüzrendészeti felügyelöt illeti meg.

8. § (1) A szervezett tűzoltóságokat törvényhatósági tűzoltószövetségekbe, ezeket pedig országos tűzoltószövetségekbe, ezeket pedig országos tűzoltószövetségbe kell tömöríteni. A szövetségi tagsági díjakról a városok és községek költségvetésében kell gondoskodni.

(2) A tűzoltószövetségek szervezetének és feladatkörének főbb szabályait, valamint a tagsági díjak legmagasabb mértékét a belügyminiszter rendelettel állapítja meg; egyébként szervezetükről és feladatkörükröl a tüzoltószövetségek alapszabályaikban rendelkeznek. Az alapszabályokat a belügyminiszter az érdekelt miniszterek meghallgatásával láttamozza. A tüzoltószövetségekkel kapcsolatos pénzügyi vonatkozású kérdésekben a belügyminiszter a pénzügyminiszterrel egyetértően jár el.

9. § (1) A tüzbiztosítással foglalkozó biztosító magánvállalatok kötelesek országos tủzrendészeti járulékot fizetni. Ezek a járulékok a biztosítottakra nem háríthatók át.

(2) A tűzrendészeti járulék alapja a biztosító magánvállalatok belföldi közvetlen tüzbiztosítási bruttó díjbevétele.

(3) A tüzrendészeti járulékot a biztosító magánvállalatok az 1935. évi szeptember hó 30-át követő időre eső díjbevételeik után kötelesek fizetni. Újonnan keletkezett vállalatoknál a járulékfizetési kötelezettség az üzlet megkezdését követő hó else- 
jével kezdődik. Megszünik a fizetési kötelezettség annak a hónapnak a végével, amelyben a vállalat üzletmüködését végleg megszüntette.

(4) A tüzrendészeti járulék kivetési kulcsát, mely 1\%-nál kisebb és 2\%-nál nagyobb nem lehet, a belügyminiszter a pénzügyminiszterrel egyetértve évenkint állapítja meg.

(5) A tủzrendészeti járulékot köteles a vállalat a Biztosító Magánvállalatok állami felügyeletéröl szóló rendelkezések értelmében fizetett felügyeleti díjakra megállapított szabályok szerint negyedévenkint a Biztosító Magánvállalatok m. kir. állami felügyeleti hatóságának minden külön felhívás bevárása nélkül befizetni s a befizetéssel egyidejüleg a belföldi közvetlen tủzbiztosítási bruttó díjbevételek naplókivonatát a felügyelöhatósághoz beterjeszteni.

(6) A járulék biztosítására, behajtására és elévülésére, továbbá a késedelmes fizetés esetében járó késedelmi kamatokra a közadók kezelésére vonatkozó rendelkezések az irányadók.

(7) A járulék késedelmes fizetése esetében rendbírság fizetendő. A rendbírság fizetési módjára az 1920:XXIV. törvénycikk 20. §-a irányadó.

(8) A tủzrendészeti járulék, valamint a rendbírság jogossága és mértéke ellen a közigazgatási bírósághoz panasznak van helye.

(9) Adócsalást követ el, aki az (5) bekezdésben megszabott naplókivonatba tudva olyan valótlan adatot jegyez be vagy abból tudva olyan való adatot hagy ki, amely alkalmas arra, hogy a tủzrendészeti járulék összege kisebbnek mutatkozzék, mint amilyen a törvény szerint járna.

(10) A tűzrendészeti járulékot, a késedelmi kamatokat, valamint a bevételek terhére teljesítendő kiadásokat az állami költségvetésben kell elöirányozni.

10. § (1) A tüzrendészet körében eljáró hatóságok hatáskörét, a tüzoltó szervezetet, a szervek feladatkörét, a tüzoltói képesítés kellékeit, a tüzoltó kiképzés és szolgálat szabályait, a tüzrendészeti felügyelőknek, valamint a tüzoltói szervezet tagjainak felügyeleti és fegyelmi szabályait és általában a tüzrendészetnek ebben a törvényben nem szabályozott részleteit a belügyminiszter az érdekelt miniszterekkel egyetértően rendeletben állapítja meg.

(2) A tüzrendészetnek ebben a törvényben és az (1) bekezdés alapján kiadott rendeletben nem szabályozott kérdéseit a törvényhatóságok és a községek szabályrendelettel szabályozzák.

11. § Nagy- és kisközségekben a belügyminiszter rendelettel éjjeliőri szolgálat kötelezettségét állapíthatja meg és az éjjeliőri szolgálat megszervezésének főbb szabályait - különös figyelemmel a tüzvész elleni védekezés követelményeire - megállapíthatja; egyébként ezt a szolgálatot a községek szabályrendeletben szabályozzák.

12. § (1) A mezőgazdasági termények közös szérün való elhelyezésének céljára szükséges ingatlan megszerzésére és megnagyobbítására - amennyiben erre községi vagy városi tulajdonban levő alkalmas terület rendelkezésre nem áll - a községet és várost az 1881:XLI. törvénycikkben szabályozott kisajátítási jog illeti meg. A kisajátítást a belügyminiszter a földmívelésügyi miniszterrel egyetértve engedélyezi.

(2) Tagosítás vagy más birtokrendezés alkalmával lehetőleg gondoskodni kell az előző bekezdésben meghatározott célra szükséges területnek a község részére megszerzéséröl.

13. § Ez a törvény kihirdetése napján lép hatályba; végrehajtásáról az érdekelt miniszterekkel egyetértően a belügyminiszter gondoskodik.

Forrás ! Corpus Juris Hungarici.

VIII.sz.melléklet

10 280/1945.ME.r.

a tüzoltóság ás a tüzrendészet újjászervezéséröl.

A minisztérium az ideiglenes nemzetgyülés által az 1945. évi szeptember hó 13. napján adott felhatalmazás alapján a következőket rendeli:

1. §. (1) Az ország területén minden olyan tennivalót, amelyet valamely jogszabály a tüzoltóság feladatkörébe utal, az egységes magyar tüzoltóság (alábbiakban: tüzoltóság) tagjai látják el.

(2) Az önkéntes tüzoltó testületek a jelen rendelet hatálybalépésével megszünnek; vagyonuk a hitelezőkkel szemben fennálló kötelezettségekkel együtt arra a községre, illetőleg városra száll át, amelynek területén müködnek. Az önkéntes tüzoltó testületek alkalmazottainak szolgálati jogviszonyában a jelen rendelet hatálybalépésével munkaadóként, a bérleti és haszonbérleti jogviszonyban pedig bérbeadóként és haszonbéreadóként, illetőleg bérlőként és haszonbérlőként az illető község (város) lép a megszünő önkéntes tüzoltó testüiéit helyébe.

(3) Az önkéntes tüzoltó testületek' javára a telekkönyvbe bejegyzett jogokat a jelen rendelet alapján az érdekelt község, illetőleg város kérelmére külön bekebelezési engedély nélkül kell a község, illetőleg város javára bejegyezni.

(4) A megszünt önkéntes tüzoltó testületek vagyonát a község, illetőleg váras tüzoltósági célokra köteles használni.

(5) A tüzoltóságnak eddigi jellegük szerinti történt elnevezése (hivatásos, önkéntes, köteles és magántüzoltóság) megszünik.

2. §. (1) Az érdekeltek önkéntes jelentkezés vagy hatósági rendelkezés alapján vétetnek fel a tüzoltóság kötelékébe.

(2) A büntető törvények alkalmazása szempontjából a szolgálatban lévő tüzoltót hajtósági közegnek kell tekinteni.

(3) A tüzoltóság minden tagja a Tüzoltók Szabad Szakszervezetének tagja, lehet.

(4) A tüzoltóságnak az a tágjai, akinek a tüzoltói szolgálat nem élethivatása, egyidejüleg más szakszervezetnek is tagja lehet.

(5) Abban a kérdésiben, hogy a tüzoltók szolgálatukat illetmény ellenében, vagy anélkül látják-e el, a 4-ik és az 5. § rendelkezései az irányadók.

(6) A tüzoltóságnak az a tagja, aki szolgálatát illetmény nélkül látja el, a természetbeni közszolgáltatások (közmunfeakötelezettség, fogat- vagy gépjármű szolgáltatás kötelezettsége stb.), továbbá a tüzrendészeti járulék, valamint a Túzoltók Szabad Szakszervezete tagsági díjainak fizetéseitől mentés és a Tủzoltók Szabad Szakszervezete által nyújtott gazdasági és- kulturális előnyökben fokozottabb mértékben részesítendők.

3. §. Minden község, továbbá minden megyei és törvényhatósági jogú város köteles tüzoltóságot fenntartani. 
4. §. (1) Községben a tűzoltósiálgot önként jelentkezőkből, ilyenek hiánya esetén a tűzoltói szolgálatra alkalma 18 - 40 éves férfiaknak tűzoltói szolgálatra hatósági rendelkezéssel való kötelezése által kell megszervezni.

(2) A községi tüzoltóság vezetője a községi tüzoltóparancsnok.

(3) A 10.000 lélekszámon aluli község tűzoltóságának tagjai - a községi tűzoltóparancsnok és a szertáros, továbbá a fontosabb munkát végző s a belügyminiszter által megjelölendő tagok kivételével - illetményben nem részesülnek.

(4) A 10.000 lélekszámon felüli község tüzoltóságának tagjai közül a (3) bekezdés szerint illetményt élvező tagokon felül illetményben kell részesíteni a községi tüzoltóparancsnok helyettesét és a község lélekszámához képest 3-10 tüzoltót is.

5. §. (1) A belügyminiszter rendelettel állapítja meg a megyei és a törvényhatósági jogú városi tüzoltóság tagjainak létszámát, valamint azt, hogy a tüzoltóság hány tagját kell illetményben részesíteni.

(2) A városi tüzoltóság szervezése tekintetében a 4. § (1) bekezdésének rendelkezését kell megfelelően alkalmazni.

(3) A városi tüzoltóság vezetője a városi tüzoltóparancsnok.

6. §. A belügyminiszter a községeket, továbbá a megyei és törvényhatósági jogú városokat — teherbíróképességük figyelembevételével — tüzoltóságuk tagjai létszámának emelésére kötelezheti.

7. §. (1) Az illetékes szakminiszterek által külön rendeletben kijelölt nagyipari, mezőgazdasági és közforgalmi vállalatok tüzoltóságot kötelesek fenntartani.

(2) Az (1) bekezdésben említett tüzoltóságok tagjait az illetékes szakminiszter javaslatára a belügyminiszter, vagy az általa erre rendelettel felhatalmazott hatósági (szerv) nevezi ki.

8. §. (1) Budapest székesfőváros, továbbá Budafok, Kispest, Pestszenterzsébet, Pestszentlőrinc, Újpest megyei városok és Albertfalva, Békásmegyer Budatétény, Csepel, Mátyásföld, Nagytétény, Pesthidegkút, Pestszentimre, Pestújhely, Rákoscsaba, Rákoshegy, Rákoskereszttúr, Rákosliget, Rákosszentmihály, Sashalom, Sorokság községek (az alábbiakban NagyBudapest) területén a tüzoltóságokat azonos irányelvek alapján kell megszervezni.

(2) A belügyminiszter által rendelettel megállapítandó esetekben a Nagy-Budapest területén lévő tüzoltóságok magasabb parancsnoki tisztét - mint törvényhatósági tüzoltóparancsnok - a Budapest székesfővárosi tüzoltóparancsnok látja el.

9. §. (1) Pest-Pilis-Solt-Kiskun vármegyének Nagy-Budapest területéhez nem tartozó, továbbá a többi vidéki törvényhatóságok területén a 8 . § (2) bekezdésében meghatározott magasabb parancsnoki tisztet a vármegyei tüzoltóparancsnok látja el.

(2) Ha a vármegye székhelye törvényhatósági jogú vagy megyei város, a városi tüzoltóparancsnok — a Budapest székesfơváros- tüzoltóparancsnoka kivételével - egyúttal vármegyei tüzoltóparancsnok is.

(3) Ha a vármegye székhelye község, külön vármegyei tủzoltóparancsnokot kell kinevezni.

10. §. (1) A 9. § értelmében külön kinevezett vármegyei tüzoltóparancsnok vármegyei tisztviselő; szolgálatát az állami tisztviselők VII. fizetési osztályában kezdi.

(2) A vármegyei tüzoltóparancsnoki tisztet is ellátó törvényhatósági jogú és megyei városi tủzoltóparancsnok (8. § (2) bek és 9. § (2) bek.) feladatkörének ellátásáért költségátalányt kap. A költségátalány összegét a vármegye terhére a pénzügyminiszterrel egyetértőleg a belügyminiszter állapítja meg.

11. §. (1) Az ország valamennyi tüzoltóságának föparancsnoki tisztét és a tüzoltósággal, valamint a tüzrendészettel kapcsolatos egyéb tennivalókat az országos tüzoltófőparancsnok látja el; feladatkörét részletesen a belügyminiszter szabályozza.

(2) Az országos tüzoltóföparancsnok az állami tisztviselök V. fizetési osztályába sorozott és közvetlenül a belügyminiszternek alárendelt állami tisztviselö.

(3) Az országos tüzoltóföparancsnok feladatkörének ellátásához szükséges személyzet létszámát és ,a személyzet szolgálati viszonyát a pénzügyminiszeterrel egyetértően a belügyminiszter állapítja meg.

(4) Az országos tüzoltóföparancsnok mellett a Tüzoltók Szabad Szakszervezetének kiküldöttje tanácsadóként müködik. A kiküldöttet az országos tüzoltóföparancsnok a tüzoltóság tagjainak személyi, szolgálati és felszerelési ügyében meghallgatni köteles.

12. §. A vármegyei tủzoltóparancsnokok és az országos tüzoltófőparancsnok müködésének megkezdésével egyidejüleg a tüzrendészeti felügyelői tisztségek és megbízatások megszünnek. A hivatásos vármegyei tüzrendészet! felügyelők, mint vármegyei tüzoltóparancsnokok tovább müködnek.

13. §. A tüzoltóságok a belügyminiszter föfelügyelete és ellenőrzése alatt állanak.

14. §. A külön vármegyei tűzoltóparancsnokot (9. § (3) bek.) a belügyminiszter, a tüzoltóság tagjait a belügyminiszter, vagy az általa erre rendelettel felhatalmazott hatóság (szerv) nevezi ki.

15. §. Községekben a belügyminiszter rendelettel éjjeliőri szolgálati kötelezettséget állapíthat meg és az éjjeliőri szolgálat megszervezésének föbb szabályait - különös figyelemmel a tüzvész elleni védelem követelményeire - megállapíthatja, egyébként a szolgálat szabályozása tárgyában a községek kötelesek a jelen rendelet hatálybalépésétől számított 3 év alatt szabályrendeletet alkotni.

16. §. A belügyminiszter a községeket továbbá a megyei és törvényhatósági jogú városokat - teherbíróképességük figyelembevételével - tűzvédelmi berendezésük kiegészítésére kötelezheti.

17. §. (1) A mezőgazdasági termények közös szérün való elhelyezésének céljára szükséges ingatlan megszerzésére és megnagyobbítására - ha erre községi vagy városi tulajdonban lévő alkalmas terület rendelkezésre nem áll - a községet és a várost az 1881 :XLI. törvénycikkben szabályozott kisajátítási jog illeti meg. A kisajátítást a belügyminiszter a földmüvelésügyi 'miniszterrel egyetértve engedélyezi.

(2) A tagosítás vagy más birtokrendezés alkalmával lehetőleg gondoskodni kell az előző bekezdésben meghatározott célra szükséges területeknek a község (város) részére való megszerzéséröl.

18. §. (1) Tüzrendészeti ügyekben - ha ez a rendelet eltérően nem rendelkezik - következő hatóságok járnak el első fokon kisés nagyközségekben a járási föjegyző, megyei városban a polgármester, törvényhatósági jogú városban a polgármester által kijelölt tisztviselö, Budapesten a kerületi elöljáró; másodfokon a törvényhatóság első tisztviselője; harmadfokon a belügyminiszter.

(2) A belügyminiszter felhatalmazást kap arra, hogy Budapest székesfőváros területén első fokú tüzrendészeti hatóságul a budapesti tüzoltóparancsnokot jelölhesse ki.

(3) A tüzrendészeti felügyeletet működésük területén a vármegyei tüzoltóparancsnok, illetőleg az országos tüzoltóföparancsnok látja el. (8., 9. és 11. §).

19. §. (1) A Magyar Országos Tüzoltó Szövetség és a törvényhatósági tűzoltó szövetségek a jelen rendelet hatályba lépésével megszünnek.

(2) A Magyar Országos Tủzoltó Szövetség vagyontárgyainak tulajdonjoga a hitelezőkkel szemben fennálló kötelezettségekkel együtt a jelen rendelet erejénél fogva a magyar államra száll át. 
(3) A törvényhatósági tűzoltó szövetségek vagyontárgyainak tulajdonjoga a hitelezőkkel szemben fennálló kötelezettségekkel együtt azokra a törvényhatóságokra száll át, amelynek területién a jelen rendelet hatálybalépésekor müködnek.

(4) Ha a vármegye területén lévő több törvényhatóság tüzoltóságai együtt alkották a törvényhatósági tüzoltó szövetséget, ennek ingatlan vagyona az 1943. évben esedékessé vált tűzoltó szövetségi tagsági díjak arányának figyelembevételével, közös tulajdonként az; érdekelt törvényhatóságokra száll át a tulajdoni arányt a belügyminiszter állapítja meg. Ilyen tüzoltó szövetségnek a hitelezőkkel szemben fennálló kötelezettségei az érdekelt törvényhatóságokra egyetemlegesség terhével hárulnak át, ingóvagyonának tulajdonjoga pedig a vármegyei törvényhatóságra száll át.

(5) Az 1. §. (3) bekezdésének a telekkönyvi bejegyzéséről szóló rendelkezését a jelen §-on alapuló vagyonátszállási tekintetében megfelelően alkalmazni kell.

(6) A tűzoltó szövetségek alkalmazottainak szolgálati viszonyával a jelen rendelet hatályba lépésével munkaadóként a Magyar Országos Tüzoltó Szövetség helyébe a magyar állam, a törvényhatósági tűzoltó szövetség helyébe Budapest székesfőváros, illetőleg az a vármegye lép, amelynek területén a tüzoltó szövetség müködött.

(7) A bérleti és a haszonbérleti jogviszonyokban a jelen rendelet hatályba lépésével bérbeadóként és haszonbérbeadóként, illetőleg bérlöként és haszonbérlőként a Magyar Országos Tüzoltó Szövetség helyébe a magyar állam, a törvényhatósági tüzoltó szövetség helyébe pedig Budapest székesföváros, illetőleg az a vármegye lép, amelynek területén a tüzoltó szövetség müködött területén a tüzoltó szövetség müködött.

(8) A (4) bekezdés esetében a belügyminiszter állapítja meg, hogy az (5) és a (6) bekezdésben említett jogviszonyok tekintetében a vármegyére háruló kötelezettségek teljesítéséhez a törvényhatósági jogú városok milyen mértékben kötelesek hozzájárulni, illetőleg a vármegye a jogviszonyokból eredő jogok átszállása címén a törvényhatósági jogú városokat milyen mértékben köteles kártalanítani.

20. §. A Magyar Országos Tüzoltó Szövetségnek a magyar államra átszálló vagyonát (19. §. (2) bek.) a belügyminiszter használatra a Tủzoltók Szabad Szakszervezetének engedi át.

21. §. (1) A tűzbiztosítással foglalkozó biztosító magánvállalatok kötelesek országos tűzrendészeti járulékot fizetni. Ezek a járulékok a biztosítottakra nem háríthatók át.

(2) A tüzrendészeti járulék alapja a biztosító magánvállalatok belföldi közvetlen biztosítási bruttó díjbevétele.

(3) A tüzrendészeti járulékot a biztosító magánvállalatok az 1944. évi december; hó 31. napját követő időre eső díjbevételeik után kötelesek fizetni. Újabban keletkezett vállalatoknál a járulék fizetési kötelezettség az üzlet megkezdését követő hónap 1-vel kezdődik. Megszünik a fizetési kötelezettség annak iá hónapnak a végével, amelyikben a vállalati üzletmüködését végleg megszüntette.

(4) A tüzrendészeti járulék kivetési kulcsát, - amely 10\%-nál nagyobb nem lehet - a pénzügyminiszterrel egyetértve a belügyminiszter állapítja meg.

(5) A vállalat köteles a tűzrendészeti járulékot Biztosító Magánvállalatok állami felügyeletéről szóló rendelkezések értelmében fizetett felügyeleti díjakra megállapított szabályok szerint, negyedévenként a biztosító magánvállalatok állami felügyeleti hatóságnak minden külön felhívás bevárása nélkül befizetni és a befizetéssel egyidejűleg a belföldi közvetlen tűzbiztosítási bruttó díjbevételek naplókivonatát a felügyelő hatósághoz felterjeszteni

(6) A járulék biztosítására, behajtására és elévülésére, továbbá a késedelmes fizetés esetében járó késedelmi kamatokra a közadók kezelésére vonatkozó rendelkezések az irányadók.

(7) A járulék késedelmes fizetése esetében rendbírság fizetendő. A rendbírság fizetési módjára \&z 1920:XXIV. te. 20. §-a irányadó.

(8) A tüzrendészeti járulék, valamint a rendbírság jogossága és mértéke ellen a közigazgatási bírósághoz panasznak van helye.

(9) Adócsalást követ el, aki az (5) bekezdésben megszabott naplókivonatban tudva olyan valótlan adatot jegyez be, vagy abból tudva olyan való adatot hagy ki, amely alkalmas arra, hogy a tüzrendészeti járulék összege a megállapítottnál kisebbnek mutatkozzék.

(10) 'A tűzrendészeti járulékot, a késedelmi kamatokat, valamint a bevételek terhére teljesítendő kiadásokat az állami költségvetésben kell elöirányozni.

22. §. Ha a belügyminiszter valamelyik községet vagy megyei, törvényhatósági jogú várost teherbíró képességén felül közérdekből kötelez tűzoltóságának vagy tűzoltói berendezésének kiegészítésére, az állam a községnek, illetőleg a városnak a teherbíró képességét meghaladó kiadásait - első sorban a 21. §-ban említett tủzrendészeti járulékból - megtéríti.

23. §. (1) A tüzoltóság szervezetének részletes szabályait, továbbá a tűzoltói kiképzés és szolgálati szabályait, a tüzoltóság tagjainak felügyeleti és fegyelmi szabályait, a tủzoltóság feladatkörét, a tüzrendészet körében eljáró hatóságok hatáskörét és általában a tüzoltóságra, valamint a tüzrendészetre vonatkozó s ebben a rendeletben nem szabályozott részleteket a belügy miniszter - az érdekelt miniszterekkel egyetértve - rendeletben állapítja meg.

(2) A tüzoltóságok szervezetének és a tüzrendészet körébe tartozó a jelen rendeletben, valamint az elöző bekezdésben említett belügyminiszteri rendeletben nem szabályozott kérdéseket a községek, a városok és a vármegyék szabályrendelettel szabályozhatják; a belügyminiszter felhívására ily tárgyú szabályrendeletet alkotni kötelesek.

24. §. (1) A községek és a városok a kellő számú tűzoltószemélyzet díjazásával, továbbá a szükséges tűzoltói felszerelés megszerzésével, a meglévő felszerelés karbantartásával és pótlásával járó kiadások részleges fedezéséröl községi, (városi) tüzrendészeti járulék szedése útján is gondoskodhatnak.

(2) A tüzrendészeti járulék mértékét a pénzügyminiszterrel egyetértve a belügyminiszter állapítja meg.

25. §. (1) A jelen rendelet kihirdetése napján (1945- nov. 13) lép hatályba; a hatályba lépésével az 1936 :X. törvénycikk egész terjedelmében hatályát veszti; úgyszintén hatályukat vesztik mindazok a jogszabályok is, amelyek a jelen rendelettel ellenkeznek, vagy azzal egyeznek.

(2) A jelen rendelet végrehajtásáról az érdekelti miniszterekkel egyetértve a belügyminiszter gondoskodik.

Budapest. 1945. évi október hó 30-án.

Miklós Béla s. $k$.

miniszterelnök.

Forrás ! Magyarországi Rendeletek Tára, LIX.évf. (1945) I. füzet. 901-904.p. 
5090/1948. korm.r.

\section{az állami tüzoltóság szervezése és a tüzoltóság szervezete tárgyában.}

1. §. (1) Mindazokat a tennivalókat, amelyeket valamely jogszabály a tủzoltóság feladatkörébe utal, részben ezzel a rendelettel megszervezett állami, részben az önkéntes jelentkezés vagy hatósági kötelezés alapján müködő tüzoltóságok tagjai foganatosítják.

A tüzoltói szolgálatot az országos tűzoltó föparancsnokságnál, továbbá Budapest székesfővárosban, minden törvényhatósági jogú és megyei városban, valamint a belügyminiszter által az illetékes szakminiszterekkel egyetértésben már kijelölt vagy kijelölendő vállalatoknál (üzemeknél) az állami tűzoltóság tagjai látják el. A felsoroltakon felül az állami tủzoltóság tagjai közé tartozik olyan vármegye tüzoltóosztályának parancsnoka is, amelynek székhelye község.

A jelen rendelet hatálybalépésével a (2) bekezdésben felsorolt tüzoltóságok tagjai az állami tủzoltóság létszámához tartoznak. A kijelölt vállalatoknál (üzemeknél) tűzoltói munkakört ellátó alkalmazottak csak abban az esetben tartoznak az állami tüzoltóság kötelékébe, ha erre vonatkozólag kinevezési okiratot kaptak.

(4) Állami tüzoltóságot kell szervezni azokban a községekben is, amelyekben a lakosság lélekszáma 15.000 föt meghalad. Azokban a községekben, amelyekben a lakosság lélekszáma a 15.000 főt nem haladja meg, a községi képviselőtestület kérelmére a belügyminiszter állami tüzoltóság szervezését rendelheti el.

(5) A belügyminiszter a tüzvédelem megszervezése érdekében több községet, illetőleg az (1) bekezdés alapján kijelölt vállalatok (üzemek) közül több vállalatot (üzemet) is egy tüzoltóság müködési körébe utalhat.

(6) A belügyminiszter a szervezés során, a tűzvédelem fokozottabb ellátása céljából, az állami tűzoltóság több egységét, illetőleg szervét összevonhatja vagy a szükséghez képest megszüntetheti, továbbá egyes tűzoltószervek parancsnokait más tüzoltószervek közvetlen felügyeletével és ellenőrzésével is megbízhatja.

(7) A (2) bekezdés alapján állami tủzoltóság szervezésére kötelezett vállalatoknál (üzemeknél) a belügyminiszter tüzoltóság szervezetén belül üzemi őrségek felállítását is elrendelheti.

2. §. Azokban a községekben és vállalatokban (üzemekben), amelyek állami tűzoltóság szervezésére nincsenek kötelezve, a tűzoltóság feladatkörét továbbra is önkéntes jelentkezés vagy hatósági kötelezés alapján megszervezett tüzoltóságok látják el.

3. §. A büntetőtörvények alkalmazása szempontjából a szolgálatban lévő tűzoltót hatósági közegnek kell tekinteni.

4.§. (1) Az ország valamennyi tüzoltósága a belügyminiszter főfelügyelete és ellenőrzése alatt áll. Az ország valamennyi tüzoltóságának főparancsnoki tisztét az országos tüzoltóparancsnok látja el, aki közvetlenül a belügyminiszternek alárendelt tisztviselö.

(2) Az országos tủzoltóparancsnok feladatkörét és szolgálati viszonyát részletesen a belügyminiszter szabályozza; a feladatkörének ellátásához szükséges személyzet létszámát a pénzügyminiszterrel egyetértésben a belügyminiszter állapítja meg.

5.§. (1) A vármegyék területén a tüzrendészeti felügyelet az országos tüzoltó főparancsnok vezetése alatt tüzoltó osztályparancsnokságok gyakorolják, amelyeknek müködésük területén - az összes városi, községi és vállalati (üzemi) tüzoltóságok alá vannak rendelve. A tüzoltóosztályok - létszámuknak megfelelően - tüzoltóalosztályokra, illetve tüzoltó őrsökre tagozódnak.

(2) Ha a vármegyei székhely, törvényhatósági jogú vagy megyei város, tűzoltóegységének parancsnoka - Pest-Pilis-SoltKiskún és Csongrád vármegyék kivételével egyszersmind a vármegye tüzoltóosztályának is parancsnoka.

(3) Pest-Pilis-Solt-Kiskún vármegyében két vármegyei tüzoltóosztályt - északpesti és délpesti tüzoltóosztályt - kell szervezni. Az északpesti osztály hatásköre Budapest székhellyel kiterjed: az alsódabasi, aszódi, budakömyéki, gödöllői, gyömrői, monori, nagykátai, szentendrei és váci járások, továbbá Budafok, Kispest, Pestszenterzsébet, Pestszentlőrinc, Rákospalota, Újpest, Szentendre és Vác megyei városok tűzoltóságaira, a délpesti tüzoltóosztály hatásköre Kecskemét törvényhatósági jogú város székhellyel kiterjed az abonyi, ceglédi, dunavecsei, kalocsai, kiskunfélegyházai, kiskunhalasi, kiskőrösi, kunszentmiklósi és nagykőrösi járások, továbbá Cegléd, Kalocsa, Kiskunfélegyháza, Kiskunhalas és Nagykőrös megyei városok tüzoltóságaira.

(4) Csongrád vármegyében a vármegyei osztályparancsnoki teendőket Szeged törvényhatósági jogú város tűzoltóparancsnoka látja el, akinek hatásköre Hódmezővásárhely törvényhatósági jogú város tüzoltóságaira is kiterjed.

(5) Budapest székesfőváros tűzoltósága önálló tűzoltóosztály, amelynek parancsnoka egyúttal az északpesti tüzoltóosztály parancsnoka is.

(6) Ha a vármegye székhelye község, külön tüzoltóosztályparancsnokot kell kinevezni.

6. §. (1) A tűzoltóságok egységeinek élén a tűzoltóosztályparancsnokok, az alosztályparancsnokok, illetőleg az őrsparancsnokok állnak.

(2) A belügyminiszter az állami tủzoltóságok tagjait a szolgálat érdekében áthelyezheti.

(3) Az állami tüzoltóságok parancsnokai kötelesek müködésük területén a tüzrendészetre vonatkozó rendelkezések megtartását ellenőrizni és evégből a szükségesnek mutatkozó vizsgálatok megtartására jogosultak. A parancsnokok részéröl ügykörükön belül kért felvilágosításokat a hatóságok, hivatalok és magánszemélyek megadni kötelesek.

7.§. (1) Az állami tủzoltóság létszámát a belügyminiszter a pénzügyminiszterrel egyetértésben, s ennek keretén belül pedig az osztályok és őrsök számát a belügyminiszter állapítja meg.

(2) Ha az állami tüzoltóság szervezésére kötelezett vállalatoknál (üzemeknél) tüzoltói munkakörben szolgálatot teljesítő alkalmazottak állami tűzoltói szolgálatra átvételüket nem kérték, vagy az állami tüzoltói szolgálat teljesítésére alkalmatlannak minősülnek, öket a vállalat (üzem) tüzoltói szolgálatuk megszünése után lehetőleg szakképzettségüknek és eddig élvezett illetményüknek megfelelő más beosztásban alkalmazhatja.

8.§. Azokban a községekben és vállalatokban (üzemekben), amelyekben az 1. § (2)- (5) bekezdése értelmében állami tüzoltóságot nem kell szervezni, a tüzoltólétszám, valamint a tüzvédelmi felszerelés megállapítása tekintetében a tüzoltó osztályparancsnok javaslatára - üzemeknél a kerületi iparfelügyelö, illetőleg a gazdasági felügyelő meghallgatása után - a törvényhatóság első tisztviselöje dönt. Ilyen ügyekben másodfokon a belügyminiszter határoz.

9.§. Az állami tüzoltóság tényleges szolgálatában álló tagjait a jelen rendelethez mellékelt I. számú kimutatásban meghatározott 25 fizetési fokozatba kell sorolni és őket az ebben a kimutatásban feltüntetett illetmények, valamint rendfokozatok illetik meg. 
10.§. (1) Az egyes rendfokozatba az állami tüzoltóság tagjai kinevezés útján jutnak és a kinevezés az illető rendfokozatra nézve megszabott fizetési fokozatra szól.

(2) Az állami tüzoltóság tagjait a 4. vagy ennél magasabb fizetési fokozatba a belügyminiszternek a miniszterelnök útján tett elöterjesztésére az államfö, az 5-17. fizetési fokozatig bezárólag a belügyminiszter, az állami tüzoltóság többi tagját pedig az országos tüzoltó főparancsnok nevezi ki.

(3) Az egyes rendfokozatokban a magasabb fizetési fokozatba az előlépés a várakozási idő elteltével kinevezés nélkül (automatikusan) következik be.

11.§. (1) A rendelet hatálybalépésével a tényleges közszolgálati alkalmazásban álló tűzoltótiszteket a jelenlegi fizetési osztályuknak megfelelő legalacsonyabb fizetési fokozatba, a tüzoltóaltiszteket, tiszteseket és tüzoltókat pedig a rendfokozatuknak megfelelő legalacsonyabb fizetési fokozatba kell besorolni.

(2) Azoknak az állami tüzoltóknak részére, akik a jelen rendelet alapján alacsonyabb illetményekben részesülnek, mint amelyet a jelen rendelet hatálybalépésekor élveznek, a különbözetet személyi pótlékként mindaddig folyósítani kell, amíg az új illetményrendszer szerinti összeget el nem érik.

(3) A (2) bekezdés rendelkezése a vállalati (üzemi) alkalmazásból állami tüzoltói szolgálatra átvett tűzoltókra nem vonatkozik.

(4) A vállalat (üzem) állami tüzoltóságának tagjául kinevezett alkalmazottat fizetési fokozatba való besorolásánál, valamint a nyugdíj megállapításánál - rangjelzésének változása nélkül - be lehet számítani azt a szolgálati időt is, amelyet az érdekelt 18. életévének betöltése után vállalati alkalmazásban magánjogi szolgálati jogviszony alapján töltött el. A beszámítás tekintetében a belügyminiszter a pénzügyminiszter hozzájárulásával határoz.

(5) Harminc napnál hosszabb megszakítás időtartamát a fizetési fokozatba sorolásnál beszámítani nem lehet.

12.§. Az állami tüzoltóság tagjai előléptetésének módozatait, valamint az egyes fizetési fokozatokban eltöltendő várakozási időt a tüzoltóság sajátos viszonyainak figyelembevételével a belügyminiszter a pénzügyminiszterrel egyetértésben rendelettel állapítja meg.

13.§. (1) Az állami tüzoltóság tagjainak nyugdíját, továbbá özvegyi és árva ellátási díjait a jelen rendelethez csatolt II. számú kimutatásban foglaltak szerint kell megállapítani. Az ellátás megállapításánál azt a fizetési fokozatot kell alapul venni, amely fizetési fokozatba a tüzoltó tényleges szolgálatban utoljára tartozott.

(2) Az (1) bekezdés nem vonatkozik azokra a nyugdíjas tüzoltókra (özvegyekre, árvákra), akiknek ellátására való igénye a jelen rendelet hatálybalépését megelőzően nyílt meg.

14.§. Az állami tűzoltóság ténylegesen szolgáló tagjainak, valamint nyugdíjasainak (özvegyeknek, árváknak), családi pótléka, lakbérsegélye, közlekedési segélye és nevelési járuléka tekintetében a közszolgálati alkalmazottakra vonatkozó jogszabályok az irányadók.

15.§. (1) Az állami tűzoltóság kötelékébe nem tartozó községek és vállalatok (üzemek) tűzoltósága tagjainak díjazásait a község elöljáróságával, illetőleg a vállalat (üzem) vezetőségével létesített megállapodás, illetőleg kollektív szerződés szabályozza, amelyeknek irányelveit a belügyminiszter állapítja meg.

(2) Az állami tűzoltóság szervezésére nem kötelezett tüzoltóságok parancsnokait és tisztjeit a belügyminiszter előzetes hozzájárulásával az országos tüzoltóparancsnok, többi tagjait pedig - a község, illetőleg a vállalat (üzem) vezetőjének javaslatára az illetékes tüzoltó osztályparancsnok nevezi ki.

16.§. (1) A tüzoltóság minden tagja szolgálati viszonyának jellegére tekintet nélkül a tüzoltóság fegyelmi szabályzatának és fenyítőjogának van alávetve.

(2) Fegyelmi eljárásnak van helye a tüzoltóság tagja ellen:

a, ha a törvényekben, a rendeletekben és a szolgálati utasításokban megszabott hivatali kötelességét súlyosan megszegi;

b, ha hivatali hatalmával visszaél

c, ha büncselekményt követ el;

d, ha korlátlan cselekvőképességét elveszti, vagy ha szolgálatát szakképzettség vagy egyéb fontos kellék hiánya miatt a megkívánt mértékben ellátni képtelen.

17.§. (1) A fegyelmi ügyekben elsőfokon határoz:

a, az országos tűzoltó főparancsnok és a hozzá beosztottak elleni ügyekben a belügyminiszter;

b, a tűzoltótisztek elleni ügyekben az országos tűzoltó főparancsnokságnál a belügyminiszter által kijelölt háromtagú fegyelmi tanács;

c, a tüzoltóság összes többi tagja elleni ügyekben az illetékes tüzoltóosztálynál a belügyminiszter által kijelölt háromtagú fegyelmi tanács.

(2) Másodfokú fegyelmi hatóság a tüzoltótisztek elleni ügyekben a belügyminiszter, a tủzoltóság többi tagja ügyében az országos tüzoltóparancsnokságnál szervezett fegyelmi tanács.

(3) Bármely fegyelmi tanács határozatát a belügyminiszter hivatalból felülvizsgálhatja.

18. §. (1) Fegyelmi büntetések az állami tüzoltóság tagjai tekintetében:

a, a fokozatos, előléptetésből való kizárás 1-3 évre terjedő időtartamra;

b, lefokozás bármely alacsony rendfokozatba;

c, állásvesztés a hozzátartozók ellátási igényének érintetlenül hagyása mellett;

d, állásvesztés a hozzátartozók ellátási igényének elvonása mellett.

(2) A 16. § (2) bekezdésének d) pontjában meghatározott esetekben a fegyelmi büntetések kiszabásának mellőzésével végelbánásnak van helye.

19. §. (1) Fegyelmi büntetések az állami kötelékbe nem tartozó tüzoltóságok tagjai tekintetében:

a, lefokozás;

$b$, pénzbüntetés;

c, elbocsátás.

(2) A pénzbüntetés tíz forintnál kevesebb és ötszáz forintnál több nem lehet. A pénzbüntetést közadók módjára kell behajtani és azt tüzoltójóléti célokra kell felhasználni.

Hatósági kötelezés alapján szolgálatot teljesítő tüzoltóval szemben az elbocsátás csak a 16. § (2) bekezdésének c) és d) pontja esetében alkalmazható. 
20.§. (1) Enyhébb szolgálati engedetlenség, mulasztás vagy szabálytalanság esetében alkalmazható fenyítő intézkedések:

a, megfeddés;

b, szabadnap elvonása, legfeljebb nyolc napig;

c, rendbüntetés, amely öt forintnál kevesebb és száz forintnál több nem lehet.

(2) A rendbüntetés behajtására és felhasználására a 19. § (2) bekezdésében foglaltak az irányadók.

21. §. Az állami tủzoltóság kötelékébe nem tartozó tủzoltókkal szemben csak a 20. § (1) bekezdésének a) és c) pontjában meghatározott fenyítö intézkedéseket lehet alkalmazni.

22. §. A fegyelmi és fenyítő eljárás részletes szabályait a belügyminiszter állapítja meg.

23. §. (1) Tüzrendészeti ügyekben - amennyiben a rendelet vagy más jogszabály másképpen nem rendelkezik - a következő hatóságok járnak el:

a, elsőfokon:

nagy- és kisközségekben a járási föjegyző, megyei városokban a polgármester, törvényhatósági jogú városokban a polgármester által kijelölt tisztviselő, Budapesten a székesfőváros tüzoltóosztályparancsnoka;

b, másodfokon:

a törvényhatóság első tisztviselöje;

c, harmadfokon: a belügyminiszter.

(2) A tüzrendészeti ügyekben eljáró és az (1) bekezdés a) és b) pontjában felsorolt elsőfokú közigazgatási hatóságok hatásköre nem terjed ki a tüzoltóság szakirányítására, továbbá a szervezési, szolgálati, ellenőrzési, személyi és fegyelmi jogkörére. A közigazgatási hatóságoknak erre vonatkozó kérelmét az illetékes tüzoltóosztályparancsnoknak kell megküldeni.

(3) Azt, hogy az ipartelepek és a közlekedési vállalatokra (üzemekre), valamint a bányák földfeletti részeire vonatkozóan tüzrendészeti ügyekben mely hatóságok, illetőleg szervek járnak el, az illetékes szakminiszterrel egyetértésben a belügyminiszter rendeletben állapítja meg.

(4) Amennyiben azt a helyi viszonyok indokolttá teszik és a szükséges előfeltételek megvannak, a belügyminiszter az elsö- és másodfokú tüzrendészeti hatósági jogkör ellátásával bármely tüzoltóalosztály vagy tüzoltóosztály parancsnokát bízhatja meg.

24. §. (1) Tüzrendészeti vagy tüzrendészeti vonatkozású ügyben döntés előtt az illetékes tüzrendészeti szakértőt mindig meg kell hallgatni, illetőleg a helyszíni szemlére mindig meg kell hívni.

(2) Tüzrendészeti szakértők:

a, a járási föjegyző mellett a járási székhelyül szolgáló község (város) tüzoltóparancsnoka,

b, Budapest székesfőváros, továbbá a törvényhatósági jogú és megyei városok polgármestere mellett a város tüzoltóságának parancsnoka,

c, az alispán mellett a tüzoltóosztályparancsnok,

d, a belügyminiszter mellett az országos tüzoltóparancsnok.

(3) A tűzrendészeti vonatkozású határozatok és intézkedések egy példányát az illetékes tűzrendészeti szakértőnek is meg kell küldeni.

(4) A tüzoltóosztályparancsnok a működése területén eljáró közigazgatási hatóság által tűzrendészeti vagy tűzrendészeti vonatkozású ügyben hozott határozat ellen fellebbezéssel élhet, de nem fellebbezheti meg a törvényhatóság első tisztviselőjének, a törvényhatósági bizottságnak, a kisgyülések és a közigazgatási bizottságnak határozatait; e hatóságoknak tüzrendészeti vagy tüzrendészeti vonatkozású ügyben hozott határozatai ellen a fellebbezés joga az országos tüzoltóföparancsnokot illeti meg.

(5) Budapest székesfővárosban tüzrendészeti vonatkozású ügyekben a kerületi elöljáró határozata ellen a tüzoltóparancsnoknak, bármely más közigazgatási hatóság határozata ellen pedig az országos tüzoltó föparancsnoknak van fellebbezési joga.

25.§. Az állami tủzoltóság tagjainak személyi járandóságait és egyéni (ruházati) felszerelésének költségeit, valamint a kiképzéssel kapcsolatos összes kiadásokat a belügyi tárca költségvetésében kell előirányozni. A belügyi tárca költségvetésében kell elöirányozni az egyes vármegyéket terhelő külön kinevezett osztályparancsnokok hasonló költségeit is.

26.§. (1) Az állami tüzoltóság szervezésére kötelezett városok (vármegyék, községek) és vállalatok (üzemek) az állami tüzoltóságnak a 25. §-ban megjelölt költségeihez a tényleges tüzoltói létszámnak megfelelő összegü hozzájárulását kötelesek kifizetni.

(2) A hozzájárulás mértékét - az érdekelt szakminiszterekkel egyetértésben - a belügyminiszter állapítja meg, ennek mértéke az 1947-48. évi költségvetésben erre a célra megállapított összegnél kisebb nem lehet.

(3) A belügyminiszter által megállapított hozzájárulást negyedévi előzetes részletekben kell megfizetni. A fizetés módozatait a belügyminiszter a pénzügyminiszterrel egyetértőleg rendelettel állapítja meg.

27. §. (1) Az állami tüzoltóságok részére beszerzendő felszereléseket, az állandóan készenlétben tartandó tüzoltószerek és eszközök számát, valamint minőségét - az önkormányzati közigazgatási testületek, illetőleg vállalatok (üzemek) vezetőinek meghallgatása után - a belügyminiszter állapítja meg.

(2) A belügyminiszter rendelkezése értelmében beszerzendő tüzoltószerekről, tűzoltóeszközökről és felszerelésekről, valamint a tűzoltóság fenntartásával és fejlesztésével kapcsolatos dologi kiadásokról továbbra is az állami tűzoltóság szervezésére kötelezett törvényhatósági jogú és megyei városok (községek), illetőleg vállalatok (üzemek) kötelesek gondoskodni, a városok és a községek évi költségvetéseikben.

(3) A költségvetés összeállításánál a helyi tűzoltóparancsnok, illetőleg az országos tüzoltó föparancsnok véleményét is figyelembe kell venni.

28.§. (1) Az állami tűzoltóságok müködésének megkezdésével a törvényhatósági jogú és megyei városok (községek), valamint a kijelölt vállalatok (üzemek) a tüzoltóságok céljaira eddig szolgáló ingóságokat (bútorokat, irodai- és tüzoltófelszereléseket, egyenruhákat, stb.) az államkincstárnak ellenszolgáltatás nélkül használatra átengedni kötelesek.

(2) Az átengedett és az érdekelt város (község), illetőleg vállalat (üzem) költségvetési keretein belül a jövőben beszerzendő ingóságokat csak az átengedő (beszerző) város (község), illetőleg vállalat (üzem) tűzoltóságának céljaira szabad felhasználni.

(3) A (2) bekezdésben foglalt korlátozás azonban nem akadályozhatja az átengedett és beszerzendő ingóságoknak, a szakszerüség és a tüzvédelem érdekében, más város (község), illetőleg vállalat (üzem) részére való ideiglenes átadását.

29. §. (1) Az állami tűzoltóságok müködésének megkezdésével a törvényhatósági jogú és megyei városok (községek), valamint a kijelölt vállalatok (üzemek) kötelesek azokat az ingatlanokat, amelyek eddig is a tüzoltóság céljaira szolgáltak vagy ennek a célnak megfelelő más ingatlanokat az államkincstárnak ingyenes használatra átengedni. 
(2) Az átengedett ingatlanokat csak az átengedő város (község), illetőleg vállalat (üzem) tűzoltóságainak céljaira szabad használni.

(3) Az átengedett ingatlan karbantartásáról az átengedő város (község), illetőleg vállalat (üzem) gondoskodik.

(4) A belügyminiszternek a 27. § (1) bekezdésén alapuló rendelkezéseihez képest és az állami tüzoltóságok fejlesztéséhez szükséges további ingatlanok megszerzéséről a törvényhatósági jogú és megyei városok (községek), illetőleg a kijelölt vállalatok (üzemek) kötelesek gondoskodni.

30.§. (1) Szökés vétségét követi el és egy évig terjedhető fogházzal büntetendő az állami tűzoltóság kötelékébe tartozó az a tủzoltó, aki abból a célból, hogy végleg kivonja magát szolgálati kötelezettsége alól, beosztását vagy rendeltetési helyét önkényesen elhagyja vagy attól távol marad.

(2) Az a tüzoltó, aki az (1) bekezdésben meghatározott cselekményt nem az ott megjelölt célból követi el, ha távolléte huszonnégy óránál tovább tartott, önkényes eltávozás vétsége miatt hat hónapig terjedhető fogházzal büntetendő.

(3) Az (1) és a (2) bekezdésben meghatározott cselekmény büntetése egy évtől három évig terjedhetö fogház, ha a cselekmény a tüzrendészeti szolgálat zavartalan ellátását veszélyeztette.

(4) A jelen § alá eső cselekmény büntetése egy évtől öt évig terjedhető fogház, ha azt a tettes olyan közveszély alkalmával követte el, amelynél a tüzoltó közremüködni köteles.

(5) Az eljárás csak a belügyminiszter vagy az illetékes tüzoltó osztályparancsnok feljelentésére indítható meg.

31.§. (1) A mezőgazdasági termények közös szérün való elhelyezésének céljára szükséges ingatlan megszerzésére és megnagyobbítására - ha erre községi vagy városi tulajdonban lévő alkalmas terület rendelkezésre nem áll - a községet és a várost az 1881: XLI törvénycikkben szabályozott kisajátítási jog illeti meg. A kisajátítást a földmívelésügyi miniszterrel egyetértve a belügyminiszter engedélyezi.

(2) A tagosítás vagy más birtokrendezés alkalmával lehetőleg gondoskodni kell az előbbi bekezdésben meghatározott célra szükséges területeknek a község (város) részére való megszerzéséröl.

32. §. A tűzoltóság szervezetének részletes szabályait, továbbá a tűzoltói kiképzés és szolgálat szabályait a tüzoltóság feladatkörét, a tüzrendészet körében eljáró hatóságok hatáskörét és általában a tüzoltóságra, valamint a tüzrendészetre vonatkozó és ebben a rendeletben nem szabályozott részleteket a belügyminiszter rendeletben állapítja meg.

33. §. (1) Ez a rendelet az 1948. évi május hó 1. napjával lép hatályba, a jelen rendelethez tartozó I. számú kimutatásban megjelölt illetményeket azonban az 1948. évi április hó 1. napjától kezdődően kell folyósítani.

(2) A jelen rendelet hatálybalépésével a 10.280/1945. M. E. számú rendelet, a 21. §-ának kivételével, (Magyar Közlöny 174. szám), továbbá a 4.900/1946. M. E. számú rendelet (Magyar Közlöny 107. szám), valamint a 9.812/1947. Korm. sz. rendelet (Magyar Közlöny - Rendeletek Tára 192-193. szám), végül a 15.600/1947. Korm. számú rendelet (Magyar Közlöny - Rendeletek Tára 295. szám) 15. §-a hatályukat vesztik. Hatályukat vesztik mindazok az egyéb jogszabályok is, amelyek a jelen rendelettel ellenkeznek, vagy azzal tartalmilag egyeznek.

(3) E rendelet végrehajtásáról a belügyminiszter gondoskodik. 